\title{
Corporate social responsibility and M\&A uncertainty
}

\author{
Mohamed Arouri \\ Université Côte d'Azur, Nice, France \\ Mathieu Gomes \\ Université Clermont Auvergne, Clermont-Ferrand, France \\ Kuntara Pukthuanthong \\ University of Missouri
}

\begin{abstract}
An ulterior version of this paper has been published in Journal of Corporate Finance: Arouri, M., Gomes, M., \& Pukthuanthong, K. (2019). Corporate social responsibility and M\&A uncertainty. Journal of Corporate Finance, 56, 176-198. DOI: https://doi.org/10.1016/j.jcorpfin.2019.02.002
\end{abstract}

\begin{abstract}
We contribute to the corporate social responsibility (CSR) literature by investigating whether the CSR of acquirers impacts mergers and acquisitions (M\&A) completion uncertainty. Using arbitrage spreads following initial acquisition announcements as a measure of deal uncertainty, we document -for an international sample of $726 \mathrm{M} \& A$ operations spanning the 2004-2016 period- a negative association between arbitrage spreads and acquirers' CSR. Specifically, we show arbitrage spreads are reduced by 1.10 percentage points for each standard deviation unit-increase in the acquirer's CSR score. Findings are qualitatively similar when we focus on individual CSR dimensions (environmental, social, and governance). Our results suggest the CSR of acquirers is an important determinant of the way market participants assess the outcome of M\&As worldwide.
\end{abstract}

Keywords: Corporate Social Responsibility (CSR), Mergers and Acquisitions (M\&A), Risk Arbitrage

JEL Classification: G34, M1 


\section{Introduction}

Enormous amounts of money flow each year as a result of mergers and acquisitions (M\&A, henceforth) transactions. In 2016, for example, no less than 48,736 M\&A transactions took place worldwide, representing an aggregate value of $\$ 3.6$ trillion, according to the Institute for Mergers, Acquisitions, and Alliances (IMAA) ${ }^{1}$. These substantial capital flows, coupled with M\&As' potential ability to create synergies but also conflicts of interest, render the study of M\&As important to academics and practitioners. However, not all M\&As attempts turn out to be successful, which raises the issue of completion risk, i.e., the risk that a deal may not be consummated. A deal can fail for a variety of reasons including shareholder opposition, regulatory intervention, financing problems or internal target resistance (Parker, 2005). In other words, the outcome of a M\&A bid depends on the assessment and opinion of many of an acquirer's stakeholders ${ }^{2}$. As a result, the way a company treats its stakeholders should play a role in the expected outcome of $M \& A$ deals.

A firm's policies and behaviors towards its stakeholders are often referred to as corporate social responsibility (CSR, henceforth). Interest in CSR has been strongly increasing for the past two decades, as evidenced by the constantly growing share of companies adopting CSR reporting ${ }^{3}$ and the similarly growing role played by Socially Responsible Investment (SRI) funds ${ }^{4}$. The substantial increase in CSR awareness has fueled an important

\footnotetext{
${ }^{1}$ Source: https://imaa-institute.org/

2 There is no common consensus as to what the concept of a stakeholder means, with hundreds of different definitions existing in the literature (Miles, 2012). According to Freeman (1984), stakeholders are "any group or individual who can affect or is affected by the achievements of the organizations objectives", i.e. shareholders, customers, employers, NGOs, governments, communities, etc.

${ }^{3}$ King and Bartels (2015)'s KPMG survey documents that 73 percent of surveyed companies worldwide issued CSR reporting in 2015 (a 32 percentage point increase relative to 2005), and that CSR reporting was undertaken by 92 percent of the world's largest 250 companies.

${ }^{4}$ According to the US SIF Foundation's 2016 Report on Sustainable and Responsible Investing Trends in the United States, more than one out of every five dollars under professional management in the United States $\$ 8.72$ trillion or more- was invested according to SRI strategies as of year-end 2015. This represents a 33percent increase since 2014.
} 
body of academic research on the financial consequences of CSR. Recent studies show that CSR impacts the market value of firms (Buchanan et al., 2018; Fauver et al., 2018; Ferrell et al., 2016; Gao and Zhang, 2015; Jiao, 2010; Lins et al., 2017; Servaes and Tamayo, 2013), the cost of capital (El Ghoul et al., 2011; Dhaliwal et al, 2014; Martínez-Ferrero et al., 2016; Ng and Rezaee, 2015), the financial risk of companies (Kim et al., 2014; Diemont et al., 2016) and the value of cash holdings (Arouri and Pijourlet, 2017; Cheung, 2016; Ghaly et al., 2015). However, existing research work has yet to achieve consensus, and whether shareholders' interests are consistent with those of other stakeholders is still an open question that deserves further empirical analysis.

In this study, we specifically examine whether the CSR of acquirers impacts the uncertainty preceding $M \& A$ deal completion, and thus contribute to the thin literature studying CSR in the M\&A context. Indeed, while there is considerable research focusing on M\&A on the one side, and on the relationship between CSR and capital markets on the other side, the association between CSR and M\&A is scarcely analyzed. This is surprising as M\&A operations offer an excellent platform to better understand the financial impacts of CSR activities. Unlike day-to-day operating decisions, M\&As potentially create positive synergies but also substantial financial and operational risks that may affect all stakeholders (Burns and Collett, 2017). Identifying the determinants of M\&A uncertainty is therefore crucial for both shareholders and other stakeholders.

There are reasons suggesting CSR should have an impact on deal-related uncertainty. On the one hand, proponents of stakeholder theory (Donaldson and Preston, 1995; Freeman, 1984; Porter and Kramer, 2006) suggest that ethical behavior and profit are not mutually exclusive and that acting in all stakeholders' interests ultimately benefits shareholders. According to this view, high CSR companies should benefit from stronger stakeholders 
commitment thanks to an increased reputation for delivering on their implicit contracts 5 . Indeed, strong CSR attributes should reduce the probability of a breach in implicit contracts and firms that have high CSR should therefore receive stronger stakeholders' support (i.e., from employees, capital providers, and authorities). This is especially important within the context of unsettling events such as M\&As. As a result, M\&As conducted by high-CSR acquirers should embed less uncertainty than operations initiated by low-CSR acquirers, and this lower uncertainty should result in reduced completion uncertainty. On the other hand, the neoclassical paradigm (Friedman, 1970; Jensen, 2001; Levitt, 1958) views CSR-related expenditures as a waste of valuable resources resulting in benefits enjoyed by non-financial stakeholders at the expense of shareholders. Following this view, M\&As conducted by highCSR acquirers should be characterized by more uncertainty than operations initiated by lowCSR acquirers because of increased risk of shareholder opposition and reduced access to capital.

In this paper, we contribute to the open debate on the capital market consequences of CSR activities and evaluate these two opposite views by empirically assessing the impact of acquirer's CSR on M\&A completion uncertainty, proxied by arbitrage spreads, using an international sample of 726 deals spanning the 2004-2016 period. Our measure of acquirer's CSR comes from ASSET4 - Thomson Reuters ESG Research Data. Our main findings offer strong evidence that M\&A completion uncertainty is negatively related to the CSR of acquirers. Indeed, we find that a one-standard deviation increase in the acquirer's CSR score reduces the deal's arbitrage spread by 1.10 percentage points. Results are qualitatively similar

\footnotetext{
${ }^{5}$ Corporations represent a nexus of implicit and explicit contracts between shareholders and stakeholders (Coase, 1937; Fama and Jensen, 1983; Shleifer and Summers, 1988). Explicit contracts refer to those contracts that have legal binding whereas implicit contracts have no legal binding. For implicit contracts, firms can miss their promise without being sued by other stakeholders. The value of implicit contracts depends on trust. HighCSR firms tend to have the reputation of being trustworthy and reliable; and are therefore expected to commit to implicit contracts (Kristoffersen et al., 2005; Liang et al., 2017).
} 
when we focus on individual CSR dimensions (environmental, social, and governance). Our evidence is robust to a battery of sensitivity tests, including alternative proxies of completion uncertainty, alternative sample specifications, and various approaches to address potential endogeneity. Our findings support arguments in the literature in favor of stakeholder theory.

To the best of our knowledge, our paper is the first international study that examines the effect of CSR on M\&A completion uncertainty. Our paper is related to the literature that analyzes CSR within the M\&A context ${ }^{6}$. The paper closest to ours is Deng et al. (2013), who study a sample of US merger deals and find that M\&A operations by high CSR acquirers take less time to complete and are less likely to fail than M\&A operations by low CSR acquirers. They also show that high CSR acquirers realize higher merger announcement returns, higher announcement returns on the value-weighted portfolio of the acquirer and the target, and larger increases in post-merger long-term operating performance. We advance this strand of the literature in several ways. First and foremost, while Deng et al. (2013) focus on US transactions, we take an international perspective. This international perspective is particularly important when studying the M\&A-CSR link. Indeed, from a firm perspective, the motivation underlying the adoption of CSR is not straightforward. As Liang and Renneboog (2017) argue, it is not clear whether firms "do well by doing good", or "do good by doing well". In addition, the authors emphasize that CSR is not necessarily a purely voluntary initiative and that CSR adoption depends on legal rules, institutional arrangements and societal preferences. As such, to study the impact of CSR, it is important to consider firms across different countries. What's more, the volume of North American deals ${ }^{7}$ as a proportion of global M\&A activity has fallen from 90.2\% of global M\&A activity (in US\$ value) in 1985 to

\footnotetext{
${ }^{6}$ See, for example, Aktas et al. (2011), Bereskin et al. (2018), Boone and Uysal (2018), Deng et al. (2013), Gomes and Marsat (2018), and Liang et al. (2017).

${ }^{7}$ Deals in which the target firm was located in North America.
} 
$51.3 \%$ in $2016^{8}$. This trend towards increased internationalization of corporate combinations raises the need to take an international perspective when studying $M \& A$. We exploit the richness of our M\&A dataset and study our research question in an international framework. Second, as Fransen (2013) highlights, it is important to examine the various dimensions of CSR separately rather than only focus on the concept as a whole. Therefore, in addition to the overall CSR, we also analyze the environmental, social, and governance dimensions individually. Third, while Deng et al. (2013) analyze the impact of CSR on the observed probability of completion and time to completion, we use a related and intuitive measure of completion risk, i.e., arbitrage spreads. In finance, most research studies rely on ex post risk instead of ex ante risk as the latter is more difficult to estimate. The ex ante risk is an opinion about risk formed at the time the decision is made and thus incorporated by investors in their decision-making calculations. The ex post risk is often a biased proxy of ex ante risk as the latter may reflect fears of adverse events that did not materialize (Jorion and Goetzmann, 1999). Fortunately, the M\&A process offers a framework in which ex ante completion risk is readily observable through arbitrage spreads. The arbitrage spread is the difference between the offer price (to be paid in cash and/or in acquirer's stock) and the market price of the target immediately following the $M \& A$ announcement. This spread provides us with an excellent proxy for ex ante uncertainty as it conveys market expectations regarding a deal's expected outcome (Jindra and Walkling, 2004). In this sense, it gives us insight into what the market thinks of the chances of a deal succeeding. Using arbitrage spreads as a measure of completion risk allows us to evaluate directly how market participants perceive CSR in the M\&A context and to examine whether investors actually price the impact of CSR on M\&A risk.

\footnotetext{
${ }^{8}$ Source: https://imaa-institute.org/
} 
Fourth, we explicitly control for target's CSR in additional tests to make sure the impact of acquirers' CSR on deal uncertainty does not depend on target's CSR performance.

Also related to our study is Liang et al. (2017) who investigate the impact of acquirers' engagement in employee issues in the $M \& A$ context. Our study differs from theirs in two important ways. First, while Liang et al. (2017) analyze M\&A wealth effects, we focus on M\&A completion uncertainty. Second, we do not focus only on employee relations but consider all dimensions of CSR (environment, social, and governance).

Finally, our study also contributes to the literature on the determinants of merger arbitrage spreads by showing that the CSR attributes of acquirers matter in explaining the cross-sectional variance of arbitrage spreads.

The remainder of this article is organized as follows. Section 2 presents the concept of risk arbitrage, the related literature, and motivates how an acquirer's CSR activities may impact M\&A completion uncertainty. Section 3 describes the data and provides summary statistics for the different variables we use. Section 4 presents empirical results, and Section 5 concludes.

\section{Risk arbitrage, corporate social responsibility, and M\&A uncertainty}

This section serves three purposes. First, we review previous research studies on M\&A and risk-arbitrage. Second, we discuss the main findings of research works on CSR. Finally, we relate the two previous literatures and motivate how CSR can be expected to impact M\&A uncertainty. 


\section{1. $M \& A$ and risk-arbitrage}

When an acquisition bid is announced, the market stock price of the acquiring firm usually goes down while the market stock price of the target firm usually adjusts upward without exactly reaching the level of the offer price (to be paid in cash and/or stock of the acquiring firm). The difference between the target stock price immediately following the acquisition announcement and the offer price is called the speculation or arbitrage spread. Arbitrage spreads are theoretically set conditional on the features of a particular acquisition and anticipating the outcome of the offer. While the bid price provides information about the bidder's valuation of the target, the arbitrage spread conveys information about the market's pricing of the target conditional on the existence of the bid (Jindra and Walkling, 2004). The arbitrage spread can therefore be seen as a result from wagers on the expected outcome of the operation by market participants: the greater the perceived risk of failure, the wider the arbitrage spread.

Risk arbitrage (sometimes called merger arbitrage) -for which investors seem to have been regaining interest recently ${ }^{9}-$ is the investment strategy aimed at profiting from this spread. In the case where the bid is successful, the arbitrageur pockets the arbitrage spread. However, if the deal fails, the arbitrageur suffers a loss usually much greater than the profit realized if the deal succeeds. For risk-arbitrageurs, the appropriate positions to undertake depend on the deal consideration structure. In cash bids, the acquirer offers to exchange cash for the target's equity. In this case, the arbitrageur simply purchases the target company's stock and earns the arbitrage spread if the offer eventually succeeds. In stock bids (all-stock or stock-and-cash deals), the arbitrageur still purchases the target company's stock but also sells short a given amount of the acquirer's stock.

$9 \quad$ https://www.bloomberg.com/news/articles/2016-04-27/hedge-fund-investors-have-fallen-in-love-withmerger-arb-again 
Several reasons have been suggested to explain risk arbitrage returns. Larcker and Lys (1987) view risk arbitrage returns as a compensation for the cost of acquiring valuable private information while Mitchell and Pulvino (2001) see them as a compensation for providing liquidity, especially in bear markets. Generally speaking, the main risk in merger arbitrage is completion risk, i.e., the risk that the deal ultimately fails. Other risks relate to the uncertainty surrounding the deal terms and the time to consummate the deal (Brown and Raymond, 1986). As risk arbitrage profits are considered a reward for bearing these risks, any change in these risks will also affect the arbitrage spread (Baker and Savoglu, 2002).

Researchers have attempted to explain the cross-sectional variations of arbitrage spreads and to find their determinants. Jindra and Walkling (2004) are the first to explore this subject. They analyze a sample of 362 US cash tender offers spanning the 1981-1995 period and find that arbitrage spreads are significantly associated with various bid and offer characteristics. They also show arbitrage spreads are positively related to offer duration and negatively related to the magnitude of price revisions. Branch and Wang (2008) analyze a comprehensive sample of 1,223 announced deal attempts occurring between 1995 and 2005 and find characteristics such as bid premia, arbitrageurs' involvement and target's relative size have an impact on arbitrage spreads. More recently, Jetley and Ji (2010) investigate the decline of risk-arbitrage returns over the 1990-2007 period and find that all-cash transactions are usually associated with narrower spreads because these transactions are less risky.

\subsection{Corporate Social Responsibility}

There are two conflicting views regarding CSR: the shareholder view and the stakeholder view. The shareholder view is rooted in neoclassical economic theory according to which the sole responsibility of managers is to maximize profit (Friedman, 1970) while social and 
environmental issues should be resolved by the market itself, within the boundaries of what is permitted by regulation and, falling that, by the government. In the same vein, Levitt (1958) criticizes beyond-compliance actions by firms and considers that the only responsibilities of businesses are "to obey the elementary canons of everyday face-to-face civility and to seek material gain". According to this view, CSR-related expenditures are seen as a waste of valuable resources that should instead be employed to maximize firm value. In this case, benefits that other stakeholders get from CSR activities come at the expense of shareholder wealth, resulting in a wealth transfer from shareholders to other stakeholders.

The stakeholder view claims that "corporate success and social welfare are not a zerosum game" (Porter and Kramer, 2006), and that CSR-related activities increase stakeholders' support towards a firm's operations and therefore ultimately benefit shareholders. As pointed out by Deng et al. (2013), this view is closely related to contract theory (Coase, 1937) according to which a firm is a nexus of explicit and implicit contracts between shareholders and other stakeholders (Shleifer and Summers, 1988). Implicit contracts are not legally binding and there is no explicit cost involved in not honoring them (Kristoffersen et al., 2005). Therefore, they carry a high amount of uncertainty and their value is thus contingent on stakeholders' expectations regarding the firm's willingness to honor its commitments (Cornell and Shapiro, 1987).

CSR activities are often associated with a stronger reputation (Martinez-Ferrero et al., 2016) and a stronger commitment to honor implicit contracts (Deng et al., 2013). This stronger reputation in turn can increase the ability to attract financial capital (Cheng et al., 2014), the appeal to current and potential employees (Fombrun et al., 2000; Branco and Rodrigues, 2006) and customer loyalty (Fombrun et al., 2000). It can also lead to more attractive contract terms with strategic partners, mainly as a result of improved trust (Barney 
and Hansen, 1994) and the ability to price products and services less aggressively (Fombrun et al., 2000).

Trust is particularly important in the context of uncertain event like M\&As. These events are likely to unsettle key stakeholders because they challenge the continuity of existing long-term relationships between the firm and stakeholders and can in some cases require stakeholders to renegotiate their contracts with the new combined entity (Deng et al., 2013). As a result, a firm's reputation for honoring its implicit commitments to stakeholders is a key determinant of a combination's success. This also explains why firms considering alliance projects are more attracted by prospective partners perceived as trustworthy (Shah and Swaminathan, 2008).

\subsection{CSR and uncertainty surrounding $M \& A$ deals}

According to the stakeholder view, strong CSR attributes should reduce the probability of a breach in implicit contracts and therefore increase stakeholders' support towards a firm. Also, a firm's commitment to explicit and implicit contracts with key stakeholders plays an important role in the wealth gains of acquiring firms' shareholders (Shleifer and Summers, 1988; Rhodes-Kropf and Robinson, 2008; Masulis et al., 2016; Liang et al., 2017). As a result, acquirers' shareholders should be less likely to oppose deals conducted by high-CSR firms. In addition, target's stakeholders could also protest and lobby against a takeover conducted by an acquirer perceived as socially irresponsible (low-CSR acquirer), potentially convincing the board to consider alternatives to the takeover (Liang et al., 2017). In addition, negative reputation spillovers from the acquirer resulting from a low CSR commitment would decrease the value of the target firm relative to other acquirers without a negative reputation (Boone and Uysal, 2018). The target firm should therefore be more inclined to oppose a M\&A 
attempt coming from a low-CSR bidder. Finally, high-CSR acquirers could also enjoy a better reputation among regulators (Hong and Liskovich, 2015), reducing the risk of regulatory intervention during the M\&A process. Therefore, mergers and acquisitions conducted by high CSR acquirers should embed less uncertainty than operations initiated by low CSR acquirers. This fact has been validated empirically in the US context. Indeed, Deng et al. (2013) find that mergers initiated by high-CSR acquirers take less time to complete and are less likely to fail than mergers initiated by low-CSR acquirers. They emphasize the fact that "high CSR acquirers effectively reduce the conflicts of interests between shareholders and other stakeholders by improving the welfare of both parties", leading to faster integration. Similarly, Hawn (2013) focuses on emerging markets and studies the importance of CSR in the expansion of multinational companies through corporate acquisitions and finds that strong CSR (by acquirers) leads to faster deal completion, implying that CSR advantage actually overcomes home country disadvantage. This is a fundamental point as arbitrageurs must not only predict the outcome of a transaction but must also estimate the time to completion. Indeed, if a deal takes significantly longer to complete than anticipated, the rate of return will decline to uneconomic levels. As a result, strong CSR by the acquirer can be expected to reduce M\&A uncertainty. Increased stakeholders' support should also reduce acquisition-related uncertainty through the channel of deal financing. In cash transactions, the ability to finance the purchase of the target may in certain circumstances create substantial risks to deal completion. As noted by Paulson (in Parker, 2005), while all buyers are confident about their ability to raise the money at the time of announcement, a rise in interest rates, an earnings decline in either the target or the acquirer, or a declining stock market may all cause financing difficulties. A strong CSR could limit this problem through its negative effect on the cost of capital resulting from a large relative size of the firm's investor base and low perceived risks 
(El Ghoul et al., 2011; Dhaliwal et al., 2014; Martinez-Ferrero et al., 2016). This reduction in financing risk could in turn lead to lower uncertainties and narrower spreads.

In contrast to this view, the advocates of the shareholder view suggest that CSRrelated activities benefit other stakeholders at the expense of shareholders. In this context, mergers and acquisitions could be perceived as benefiting other stakeholders at the expense of shareholder wealth, thereby leading shareholders to vote against the deal proposal and delaying (or even blocking) completion. In addition, according to the agency view of CSR (Jensen, 2001), managers cannot maximize more than one objective function at the same time. Jensen (2001) claims that without a single and clearly stated corporate objective which should be shareholder wealth maximization - self-interested managers have greater latitude to pursue their own interests at the expense of shareholders'. Also, the overinvestment hypothesis of Barnea and Rubin (2010) argues that managers may seek to overinvest in CSR-related activities for their private benefit. They could indeed strategically commit themselves to socially responsible activities aimed at gaining stakeholders' support to ultimately strengthen their own position within the firm (entrenchment strategy). This behavior is detrimental to shareholder wealth, and such firms should therefore exhibit a higher cost of capital, reducing their financing capabilities and weakening their acquisition power. These features should lead to a higher uncertainty surrounding deal completions.

The nature of the impact of CSR on M\&A uncertainty is therefore an empirical question. We address this question in the remainder of this paper. 


\section{Data}

\subsection{Sample selection}

Our sample consists of international bids (successful and unsuccessful) announced between 2004 and 2016. The initial sample of deals comes from Thomson Financial's Securities Data Company (SDC) Platinum database. Our final sample includes all bids that meet the following five selection criteria: (1) the deal value disclosed in SDC is greater than \$1 million, (2) the acquirer initially owns less than $50 \%$ of the target firm and seeks to acquire more than $50 \%$ of the target firm, (3) the acquirer and target are publicly traded and have financial data available from the Thomson Reuters Datastream database, (4) the acquirer is rated by ASSET4, and (5) bids have standard terms, i.e., they do not feature contingent claims in the form of embedded options. These restrictions result in a final sample of 726 deal offers.

\subsection{Measure of arbitrage spread}

Arbitrage spreads are computed one day after the offer announcement date (Jetley and Ji, 2010). For cash deals, risk arbitrage involves buying the stock of the target after the merger has been announced and in this case, the arbitrage spread is computed as follows:

ArbSpread $_{\text {cash }, \mathrm{t}}=\frac{\mathrm{P}_{\text {offer }}-\mathrm{P}_{\text {target }, \mathrm{t}}}{\mathrm{P}_{\text {target }, \mathrm{t}}}$

where ArbSpread cash, $t$ is the arbitrage spread for a cash deal on trading day $t, P_{\text {offer }}$ is the price in cash offered by the acquiring company for each share of the target company's common stock and $\mathrm{P}_{\text {target, }}$ is the closing price of the target company's common stock on trading day t. 
For stock deals (i.e., mergers in which target shareholders receive shares of the acquiring firm), risk arbitrage involves buying one share of the target firm and short selling a given number of shares of the acquiring firm according to the exchange ratio (i.e., the number of shares of the acquiring firm's common stock offered in exchange for one share of the target firm's common stock). In this case, the arbitrage spread is computed as follows:

ArbSpread $_{\text {stock,t }}=\frac{P_{\text {acquirer }, t} \times \text { ER }-P_{\text {target, }}}{P_{\text {target }, \mathrm{t}}}$

where ArbSpread stock,t $_{\mathrm{t}}$ is the arbitrage spread for stock deals on trading day $t, \mathrm{P}_{\text {acquirer, } \mathrm{t}}$ is the closing price of the acquiring firm's common stock on trading day $t$, ER is the exchange ratio i.e., the number of shares of the acquirer's common stock offered to the target's common shareholders in exchange for one share of the target's common stock and $\mathrm{P}_{\text {target,t } \mathrm{t}}$ is the closing price of the target company's common stock on trading day $t$.

\subsection{Measure of a firm's CSR}

To proxy for CSR, we use the data provided by ASSET4 Thomson Reuters ESG Research Data. The ASSET4 ESG database has a reputation as one of the most diligent and trustworthy sources for CSR data (Stellner et al., 2015). It includes 5,000 global publicly listed companies and provides history up to fiscal year 2002 for close to 1,000 companies. The overall rating is based on approximately 700 individual data points, which are combined into over 250 key performance indicators (KPIs). These KPI scores are aggregated into a framework of 18 categories grouped within 4 dimensions (Economic, Environmental, Social, and Governance) that are integrated into a single overall score using equal weighting. In year $t$, a firm receives a 
z-score for each of the pillars, benchmarking its performance against the rest of the firms based on all the information available in fiscal year $\mathrm{t}-1$ (by construction, this variable is lagged by one year). The resulting percentage is therefore a relative measure of performance, zscored and normalized to be comprised between 0 and 100\%. We follow Cheng et al. (2014) and Stellner et al. (2015) and compute a firm's overall CSR score by averaging the scores assigned to the environment, social, and governance dimensions. In this study, we use for each deal the last available ASSET4 ESG score before the announcement date.

\subsection{Other variables influencing arbitrage spreads}

To investigate the relation between acquirer's CSR and arbitrage spreads and make sure our CSR measure does not proxy for other known factors that influence arbitrage spreads (Branch and Yang, 2003; Branch and Wang, 2008; Cornelli and Li, 2001; Hoffmeister and Dyl, 1981; Jennings and Mazzeo, 1993; Jetley and Ji, 2010; Jindra and Walkling, 2004; Walkling, 1985), we include several firm and deal-related controls in our regressions. Specifically, we include the bid premium, the target's cumulative return prior to deal announcement, abnormal trading volume around announcement, acquirer size, target size, the target's market-to-book ratio, the acquirer's Tobin $Q$ and previous market-adjusted return. We also include variables that can be thought of as being related to the propensity of firms to invest in CSR activities such as firm age, financial performance (return on asset), or other investment/expenses potentially linked to CSR due to limited resource availability such as capital expenditures, R\&D expenses, and advertising expenses (Campbell, 2007; Shane and Spicer, 1983; Sun and Gunia, 2018; Teoh et al., 1999; Withisuphakorn and Jiraporn, 2016). Finally, we include a set of dealspecific characteristics (cash dummy, hostile dummy, cross-border dummy, diversifying dummy, toehold dummy and multiple bids dummy). We winsorize all financial variables at the 
$1 \%$ and $99 \%$ level $^{10}$. Table A1 in the appendix provides the full description, calculation method and predicted sign of the relationship with arbitrage spreads for the control variables.

\section{Empirical Analysis}

\subsection{Distribution of the sample and arbitrage spreads}

Table 1 shows the yearly-partitioned distribution of deals and arbitrage spreads for our sample of 726 deals over the 2004-2016 period. The majority of deals are clustered in more recent years with about $70 \%$ of offers taking place in or after 2010 . The percentage of deals associated with negative arbitrages spreads ranges from $11.11 \%$ in 2005 to $38.10 \%$ in 2010 . Over the whole sample period, the number of cases with negative arbitrage spreads accounts for $24.93 \%$ of our observations. Among the 726 deals, 529 deals (73\%) were eventually successful and the remaining 197 deals (27\%) ultimately failed. In terms of deal structure, $57 \%$ of deals involve a cash-only payment while the remaining $43 \%$ are cash-and-stock or stock-only offers. The number of hostile bids is relatively low with only 47 observations (3.6\%). Finally, our sample comprises 286 cross-border deals (39\%).

[Insert Table 1 about here]

Our sample is geographically diverse with 45 countries involved. Table 2 shows a detailed distribution of deal offers across countries along with their values for the top 20 target and acquiring countries based on the number of deal offers. Not surprisingly, the United States are by far the most active market over the sample period, both as an acquirer and as a target, with 294 offers as acquirer (totaling \$2,437 billion) and 325 offers as target (totaling $\$ 2,647$ billion). Australia, Canada, France, Japan and the UK are the other main countries involved in

10 To check whether our results are robust to the inclusion of outliers, we also conduct our tests without winsorizing. Results are similar and are available upon request. 
deal attempts, both as acquirers and targets (with these countries cumulatively totaling $\$ 1,185$ billion as acquirers and \$962 billion as targets).

[Insert Table 2 about here]

\subsection{Summary statistics results}

Table 3 reports summary statistics related to our set of variables. The mean and median arbitrage spreads are $3.70 \%$ and $2.20 \%$ respectively, with a standard deviation of $7.10 \%$. The average acquiring firm in our sample has a CSR score of $59.90 \%$ and a market-to-book ratio of 3.20. The average premium offered for the target is $34.30 \%$. Correlations among these explanatory variables are reported in Table 4. None of our variables are highly correlated, ruling out potential multicollinearity issues. Interestingly, the correlation between arbitrage spreads and acquirers' CSR scores is significantly negative. In addition, we see that arbitrage spreads are positively correlated with the bid premium, and negatively correlated with the target's cumulative returns and acquirer size. These facts are in line with what we described above.

$$
\begin{aligned}
& \text { [Insert Table } 3 \text { about here] } \\
& \text { [Insert Table } 4 \text { about here] }
\end{aligned}
$$

\subsection{Multivariate analysis of the link between CSR and M\&A uncertainty}

As discussed in the introduction, despite increased academic interest in CSR and a large volume of research on M\&A, we still know very little about how CSR relates to M\&A risk. The purpose of our study is to address this gap in the literature by empirically examining the link between acquirers' CSR and M\&A arbitrage spreads. To assess the impact of acquirers' 
CSR on M\&A perceived uncertainty, we regress the arbitrage spread on a measure of acquirer's CSR and the set of control variables previously described. Our main model is as follows ${ }^{11}$ :

ArbSpread $_{i}=\beta_{0}+\beta_{1}$ AcqCSR $_{i}+\beta_{k} \sum$ Controls $_{i}+\gamma+\vartheta+\varphi+\varepsilon_{i}$

where $A_{c q C S R}$ is the acquirer's CSR score and Controls is a vector of control variables (introduced in section 3.4. and described in Table A1 of the appendix). $\gamma, \boldsymbol{\vartheta}$, and $\varphi$ represent year, industry, and country fixed-effects, respectively ${ }^{12}$. In order to better assess how the CSR of acquirers impacts the arbitrage spread, we test the overall CSR score as well as the scores for each ASSET4 CSR dimensions, namely Environment, Social, and Governance. AcqCSR is the acquirer's overall CSR score in column 1 of Table 5, the acquirer's environmental score (AcqENV) in column 2, the social score (AcqSOC) in column 3, and the governance score (AcqGOV) in column 4. To address potential endogeneity concerns, we perform Ramsey's (1969) Regression Specification Error Test (RESET) for omitted variables. Results fail to reject the null hypothesis of no omitted variable, and therefore suggest our model does not suffer from this misspecification.

Table 6 presents our results. In column 1, we run our main model using the overall ASSET4 CSR score as our CSR measure. The coefficient associated with AcqCSR is negative and statistically significant at the $1 \%$ level. This suggests that arbitrage spreads are negatively related to the acquirer's CSR. More precisely, the coefficient associated with the acquirer's

\footnotetext{
${ }^{11}$ In unreported tests, we also specify a model including a squared CSR term to account for potential nonlinearity in the relationship between CSR and arbitrage spreads. We find no evidence of non-linear association.

12 Using country and year dummies assumes that whatever is going on in a given year affects all of the countries the same. To make sure this assumption is acceptable, we also run our model using country-year fixed effects. Results are similar under this specification and are available upon request.
} 
CSR, AcqCSR is -0.046 (t-statistic $=-2.92)$. Descriptive statistics presented in Table 3 report that the standard deviation of AcqCSR is 0.240 . Therefore, the regression coefficient implies that arbitrage spreads are reduced by 1.10 percentage points for each standard deviation unit-increase in the acquirer's CSR score. ${ }^{13}$ For a target valued at $\$ 100$ million, a one-standard deviation increase in acquirer CSR would result in a \$1.1 million decrease in the arbitrage spread's dollar-value, which can be seen as the completion uncertainty expressed in terms of potential market capitalization, or the amount to be monetized by risk-arbitrage investors. This 1.10-percentage point reduction amounts to approximately $30 \%$ of the average arbitrage spread (3.73\%), making it economically significant. In addition, we also test scores for each individual CSR dimension, namely Environment, Social, and Governance. Results are presented in columns 2 to 4 and show that each CSR dimension is negatively related to arbitrage spreads at usual significance levels (5\%). In terms of economic interpretation, results imply that an increase of one standard deviation in the acquirer's environmental, social, and governance performance, are associated with a reduction in arbitrage spreads of $0.84,0.92$, and 0.75 percentage points, respectively ${ }^{14}$.

Coefficients associated with control variables are mostly in line with what we expected. Similar to Jindra and Walkling (2004), we find that the bid premium is positively linked to arbitrage spreads, whereas target's cumulative price return and deal hostility decrease arbitrage spreads. An increase in target's share price before the announcement as measured by cumulative price return can be an indicator of shifts in ownership distribution, which is associated with increased speculative activity, the accumulation of shares in more neutral

\footnotetext{
131.10 percentage points represents the product of the coefficient associated with acquirer's CSR reported in column 1 of Table 5 and the standard deviation of acquirer's CSR reported in Table 3 or -0.046 multiplied by 0.240 , respectively.

${ }^{14}$ In additional tests, we replace AcqCSR by a dummy variable taking the value of one for high CSR acquirers (i.e., acquirers with a CSR score located above the median of our sample). Results remain strong and robust. They are available upon request.
} 
hands, and therefore a decrease in arbitrage spreads (Jindra and Walkling, 2004). Hostile deals are often associated with multiple bidders, target resistance and a higher likelihood of bid revision, thereby decreasing spreads (Jennings and Mazzeo, 1993). In contrast to Jindra and Walking (2004) who find abnormal volume and toehold are negatively related to arbitrage spreads, we find they are insignificant. In a recent study, Buehlmaier and Zechner (2017) study how returns of merger arbitrage spread are determined by content of media and find that the bid premium, acquirer's size and cash flow, and target's size and market-tobook ratio do not significantly impact arbitrage spread. In contrast to BuehImaier and Zechner (2017), we find that the bid premium, target's size and market-to-book ratio are positively associated with arbitrage spreads while acquirer's size is negatively linked to arbitrage spreads. As target's size and valuation increase, so do target's resources to oppose the attempt (Hoffmeister and Dyl, 1981) and because the probability of takeover success therefore decreases, arbitrage spreads should be wider as a result. Regarding acquirer size, larger acquirers might be able to hire prestigious underwriters whose expertise allows them to estimate the offer price maximizing the probability of success, thereby decreasing arbitrage spreads. In addition, large acquirers may enjoy an easier access to capital, reducing deal financing uncertainty and therefore reducing arbitrage spreads. Although some coefficients associated with our controls may differ in terms of statistical significance from those available in the extant literature, the signs of these coefficients are consistent with those predicted by theory. The difference in statistical significance between our results and the extant literature is mainly due to sample differences including period, countries, and model specifications. Our sample period is from 2004 to 2016 covering 45 countries, Jindra and Walking (2004)'s sample is from 1981 to 1995 covering only US firms, and Buehlmaier and Zechner (2017) focus on US firms from 1999 to 2009. In addition, cash deals, and deals 
involving multiple bidders appear to be associated with narrower arbitrage spreads, again confirming the expected association. Acquirer proxies of management quality (Tobin's $Q$ and previous market-adjusted return) as well as other acquirer characteristics (ROA, CAPEX, Cash flows, R\&D, advertising and age) do not appear to have an influence. The cross-border nature of deals does not seem to impact arbitrage spreads. Overall, our results suggest that more socially responsible firms are perceived by the market as more capable of successfully and timely completing mergers and acquisitions ${ }^{15}$.

To confirm this interpretation and make sure the findings of Deng et al. (2013) are robust across countries, we follow their methodology and analyze the impact of CSR on the probability of deal completion using Probit regression in which the dependent variable is a dummy variable that equals one if the deal is completed and zero otherwise. Results are reported in Table 6 and show that the probability of completion increases with the acquirer's CSR score. Analyzing individual dimensions, we report that environmental performance (column 2) and social performance (column 3) are both positively associated with the probability of deal completion while governance (column 4) has no impact. Overall, these results suggest that CSR affects the likelihood of deal completion and that market participants anticipate this as evidenced by smaller merger arbitrage spreads.

[Insert Table 5 about here]

[Insert Table 6 about here]

\footnotetext{
${ }^{15}$ To further control for country or institutional factors, we also run our model focusing on US deals only. Results are not materially different under this specification and are not reported due to limited space. They are available upon request.
} 


\subsection{Robustness tests}

\subsubsection{Alternative measure of $M \& A$ uncertainty}

Arbitrage spreads are usually computed one day after deal announcement. However, following Branch and Wang (2008), we also test the arbitrage spread two days after announcement in order to allow the market more time to absorb the deal-related information fully. Results are reported in column 1 of Table 7 and confirm the negative relationship between acquirers' CSR and M\&A uncertainty, albeit at a slightly lower level of significance (5\%).

\subsubsection{Accounting for the financial crisis}

Our sample comprises various deals initiated during the 2007-2009 financial crisis. It is therefore possible that our results could be biased by particular behaviors characterizing periods of economic distress. In addition, if the impact of CSR on firms is more salient during periods of market stress (Lins et al., 2017), including deals announced over this crisis period could results in misestimating the impact of CSR on arbitrage spreads. In this sub-section, we control for this potential issue by removing from our sample all deals announced during the financial crisis period as defined by the National Bureau of Economic Research (NBER), i.e., ranging from December 2007 to June 2009. There are 56 deals in our sample that were announced during this period. We remove them and re-estimate our model. Results are presented in column 2 of Table 7 and confirm the negative and statistically significant (at the $1 \%$ level) relationship between acquirer's CSR and M\&A uncertainty. 


\subsubsection{Removing financial firms}

Several papers (Jindra and Walkling, 2004; Deng et al., 2013) exclude financial firms from their investigations as financial industries have different reporting policies and are subject to different regulations. To make sure our results are not biased by the inclusion of financial firms, we remove deals involving financial firms and re-estimate our model. The exclusion of financial industry deals reduces the sample size by 122 deals. Results are reported in column 3 of Table 7. Again, acquirer's CSR appears to bear a negative and statistically significant relationship with arbitrage spreads, confirming our previous conclusions.

\subsubsection{Excluding negative arbitrage spreads}

In this sub-section, we remove from our sample the deals that exhibit negative arbitrage spreads. Negative arbitrage spreads may be less intuitive to understand. In fact, they occur as a result of increased speculation regarding the possibility of an offer price revision by the current bidder, or an expected higher offer coming from a competitive bidder. This, in turn, could bias our results by adding to the conditional pricing of the deal an extra layer of speculation on top of the assessment of completion risk. Removing these deals reduces our sample to 545 deals. Results are reported in column 4 of Table 7, and confirm our previous findings. Indeed, the association between acquirer's CSR and arbitrage spreads remains negative and statistically significant (at the $1 \%$ level).

\subsubsection{Excluding US deals}

The US are the largest covered country and US deals account for a significant proportion (33\%) of our sample (237 out of 726 deals). In order to address a potential sample bias and make sure our results are not driven by the US, we remove these US deals from our sample. 
The exclusion of those deals reduces the sample size to 489 observations. Results are reported in column 5 of Table 7. Again, acquirer's CSR appears to bear a negative and statistically significant relationship with arbitrage spreads (at the 1\% level).

[Insert Table 7 about here]

\subsubsection{Accounting for target's CSR}

Recent studies show that CSR similarity between acquirer and target can have an impact on M\&A operations. For example, Bereskin et al. (2018) find that firms that are similar in terms of CSR are more likely to merge and that these mergers are associated with greater synergies, superior long-run operating performance, and fewer goodwill impairments. Lee et al. (2018) reach similar conclusions focusing on human capital relatedness while Boone and Uysal (2018) show similar findings by analyzing the environmental dimension. Target's stand-alone CSR could also have an influence on arbitrage spreads. Indeed, as shown by Cumming et al. (2016), manipulation (which can be thought of as the negative of CSR) by target insiders can increase the risk of deal withdrawal. In light of these elements, target's CSR policies could also play a role in driving deal completion uncertainty. In order to make sure our results are not biased by the omission of target's CSR data, we include target's CSR score in our model:

$\operatorname{ArbSpread}_{i}=\beta_{0}+\beta_{1}$ AcqCSR $_{i}+\beta_{2} \operatorname{TarCSR}_{i}+\beta_{k} \sum$ Controls $_{i}+\gamma+\vartheta+\varphi+\varepsilon_{i}$

where AcqCSR is the acquirer's CSR score, $\operatorname{TarCSR}_{\mathrm{i}}$ is the target's CSR score and Controls is a vector of control variables (introduced in section 3.4. and described in Table A1 of the appendix). $\gamma, \vartheta$, and $\varphi$ represent year, industry, and country fixed-effects, respectively. The 
additional requirement of having CSR data for both the acquirer and target reduces our sample size from 726 to 404 deals. Results are presented in Table 8 and confirm our previous findings in that acquirer's CSR remains negatively related to arbitrage spreads at conventional statistical significance levels while target's CSR does not seem to have an impact ${ }^{16}$.

[Insert Table 8 about here]

\subsubsection{Accounting for endogeneity}

One could argue that endogeneity could be a concern in this context. First of all, our dependent variable, i.e., the arbitrage spread, includes the offer price made by the acquirer and it could be argued that the acquirer's bidding behavior might be correlated with its CSR characteristics. We alleviate this concern by 1 ) including the bid premium in our model and 2) showing that the bid premium is not correlated with CSR as evidenced in Table $4{ }^{17}$.

Another potential concern would be that of CSR being a proxy for management quality. To address this omitted variable concern, we explicitly include proxies of management quality in our regression, namely Tobin's $Q$ and previous market-adjusted return (Deng et al., 2013; Lang et al., 1989). To make sure CSR does not proxy for other financial characteristics and does not result from the availability of limited resources (Sun and Gunia, 2018), our model also includes measures of performance (ROA), investment (CAPEX and $R \& D)$, and advertising expenses.

\footnotetext{
${ }^{16}$ We also tried replacing target's CSR by the CSR difference between acquirer and target. Results are similar in that only acquirer's CSR impacts arbitrage spreads. They are available upon request.

${ }^{17}$ To confirm this fact in a multivariate context, we also regress the CSR of acquirers on the bid premium and the list of controls included in equation 3. The absence of association between CSR and the bid premium is confirmed.
} 
One could also argue that managers may opportunistically invest in CSR activities in order to improve their odds of being successful acquirers, raising the issue of reverse causality. However, because acquiring CSR capabilities is a lengthy and complicated process, investing in CSR for the sole purpose of increasing the probability of deal completion would probably be a valid consideration for frequent acquirers only. In order to address these concerns, we repeat our analysis excluding serial acquirers from our sample ${ }^{18}$. Specifically, we follow Billett and Qian (2008) and define serial acquirers as firms that acquire at least two targets within any five-year horizon. There are 114 such firms in our sample and their exclusion therefore reduces our sample to 612 observations. We report the results in Table 9. We see that the removal of serial acquirers does not alter our previous conclusions in that CSR scores (overall and by dimensions) are negatively related to arbitrage spreads.

[Insert Table 9 about here]

To further address potential endogeneity problems, we also estimate instrumental variable regressions (two-stage-least-squares or 2SLS). In the first stage, we estimate ordinary least square regressions to predict the value of AcqCSR, AcqENV, AcqSOC and AcqGOV, i.e., we regress our CSR measure on explanatory variables used in Equation 3 and on two instrumental variables. For the choice of instruments, we base our work on loannou and Serafeim (2012) who show that CSR is determined by both country and industry characteristics. More precisely, a firm'S CSR is impacted by a time-invariant component associated with its membership in the country-industry pair, and a time-varying component at the country level (Cheng et al., 2014). In other words, a firm's CSR is impacted by the CSR of

\footnotetext{
${ }^{18}$ Removing serial acquirers also solves the potential issue of deals dependences within the same firms.
} 
other firms within the same industry-country pair, and by the CSR of other firms in the same country over time. We follow Cheng et al. (2014), Arouri and Pijourlet (2017), and Gomes and Marsat (2018), and use as instruments the country-year mean of CSR scores and the countryindustry mean of CSR scores, computed using the entire ASSET4 ESG database. To further support our choice of instruments, in each 2SLS regressions we perform the following two tests: (1) a Cragg and Donald (1993) instrument relevance test to ensure the relevance of our instruments (i.e., high correlations between the instruments and adjusted CSR), and (2) a Sargan (1958) overidentification test to investigate the exogeneity of our instruments (i.e., no significant correlation between the instruments and the residuals in the arbitrage spread regressions $)^{19}$. Results are presented in Table 10.

[Insert Table 10 about here]

In the first-stage regressions reported in columns 1, 3, 5 and 7, we see that both instruments are statistically significant, which seems to validate their use. In the second-stage regressions, we substitute the predicted values of our CSR measures for the actual CSR scores and report results in columns 2, 4, 6 and 8 . These results confirm our previous findings in that the predicted values of our CSR measures for overall, environment, social, and governance performance are negatively associated with arbitrage spreads at usual significance levels.

\footnotetext{
19 In unreported results, we control for potential self-selection bias by following the Heckman (1979) two-stage procedure. Indeed, Firms with certain characteristics could choose to become high-CSR firms. Specifically, in the first stage, we run a Probit regression in which the dependent variable is equal to one if the firm's CSR is higher than the sample median and zero otherwise and the independent variables are the instrumental and control variables used in Tables 6 and 10. In the second stage, we estimate an ordinary least square (OLS) regression of arbitrage spreads on acquirer's CSR, the inverse Mills ratio and the control variables used in Table 6. Results remain qualitatively similar, indicating that self-selection bias is unlikely to affect our findings.
} 


\subsection{Discussion}

Overall, our results suggest that high CSR by the acquirer tends to reduce the uncertainty surrounding mergers and acquisitions and leads to narrower arbitrage spreads. In accordance with the stakeholder view, one could explain this fact by arguing that strong CSR attributes possibly reduce the probability of a breach in implicit contracts, and increase stakeholders' support towards a firm. More specifically, this reduction in M\&A perceived uncertainty may come from four sources. First, we argue that target firms' stakeholders are less likely to oppose the acquisition attempt if it comes from a socially responsible firm, because of the increased reputation associated with corporate social performance (Martinez-Ferrero et al., 2016) ${ }^{20}$. Indeed, a M\&A attempted by a socially irresponsible firm could lead target's stakeholders to protest and lobby against the takeover, and this lobbying pressure could in turn potentially convince the board to consider alternatives to the takeover (Liang et al., 2017). In addition, negative reputation spillovers coming from a low-CSR acquirer would potentially decrease the value of the target firm relative to other acquirers with better CSR credentials (Boone and Uysal, 2018), and the target firm should therefore be more inclined to oppose a M\&A attempt coming from a low CSR bidder. Strong CSR by the acquirer should therefore lead to a reduced probability of target resistance. Second, we also explain the impact of CSR on M\&A uncertainty by the reduction of conflict-of-interest risk between shareholders and other stakeholders, which facilitates the acquisition process and leads to faster integration (Deng et al., 2013). Indeed, a strong CSR performance is often associated with a stronger commitment to explicit and implicit contracts with key stakeholders (Deng et al., 2013; Liang et al., 2017). This stronger commitment to explicit and implicit contracts has

\footnotetext{
${ }^{20}$ This result is confirmed within our sample. Using Fortune's World's most admired companies ranking, we find that firms present in the index feature a CSR score which is $17 \%$ higher on average, compared with firms which are not present in the index. Results are not reported for the sake of brevity but are available upon request.
} 
an impact on the wealth gains of acquiring firms' shareholders (Shleifer and Summers, 1988; Rhodes-Kropf and Robinson, 2008; Masulis et al., 2016; Liang et al., 2017). As a result, acquirers' shareholders should be less likely to oppose deals conducted by high CSR firms. Third, we argue that CSR reduces M\&A completion uncertainty through its impact on deal financing, as empirical studies have shown that a strong CSR commitment leads to a lower cost of equity capital (El Ghoul et al., 2011; Dhaliwal et al., 2014; Martínez-Ferrero et al., 2016), a lower cost of debt (Goss and Roberts, 2011; Oikonomou et al., 2014) ${ }^{21}$, and an easier access to finance (Cheng et al., 2014). As a result, M\&A operations conducted by high-CSR firms should embed less financing uncertainty. Fourth, a strong CSR commitment could potentially improve a firm's image among regulators (Hong and Liskovich, 2015) and reduce the probability of regulatory intervention during the M\&A process.

We also show that the negative impact of acquirer's CSR on deal uncertainty does not depend upon the CSR credentials of target firms.

Finally, our study interestingly complements the findings of Deng et al. (2013) in that we find the negative link between CSR and M\&A completion risk holds internationally. Our study confirms this reduction in M\&A completion risk associated with strong CSR is priced by market participants before deal conclusion, ruling out a potential anomaly in the conditional pricing of targets.

\section{Conclusion}

In this paper, we conduct the first international study on the impact of Corporate Social Responsibility (CSR) on Mergers \& Acquisitions (M\&A)completion uncertainty as measured by

\footnotetext{
${ }^{21}$ Our sample also confirms this relationship. High CSR acquirers (see definition in section 4.1.) have a weighted average cost of capital that is 2.1 percentage points lower on average than Low CSR acquirers. Results are not reported for the sake of brevity but are available upon request.
} 
arbitrage spreads. We rely on the literature on CSR and develop two competing views (shareholder view vs. stakeholder view) about the effect of an acquirer's CSR on M\&A uncertainty. The shareholder view suggests that high-CSR acquirers should face higher uncertainty when conducting acquisitions; as a result, M\&As undertaken by high-CSR acquirers should be characterized by wider arbitrage spreads. In contrast, the stakeholder view predicts that high-CSR acquirers should be more capable of quickly and successfully completing M\&As; therefore, M\&As undertaken by high-CSR acquirers should be characterized by less uncertainty and narrower arbitrage spreads.

Using an international sample of 726 deals announced between 2004 and 2016 and controlling for other determinants previously identified in the literature, we find that deals conducted by firms with strong CSR are associated with lower uncertainty as evidenced by narrower arbitrage spreads. This empirical result is consistent with the stakeholder view. In addition, we also examine the individual impact of each CSR dimension (Environment, Social, and Governance) and find that performance in all dimensions is negatively associated with M\&A uncertainty. Our results demonstrate robustness in terms of alternative measures of arbitrage spreads as well as different sample specifications. In addition, we show that the negative impact of acquirer's CSR on deal uncertainty holds regardless of the CSR performance of the target. We also show our results are not affected by endogeneity bias.

Overall, our findings contribute to the M\&A and CSR literatures by showing how CSR influences the way markets assess the expected outcome of M\&As. We show that CSR is an important determinant of the perceived risk surrounding M\&A operations. 


\section{Acknowledgement}

We thank the "Value \& CSR" chair for providing the CSR data. We are grateful to Douglas Cumming (the editor), and two anonymous referees for their constructive comments. We also thank Sylvain Marsat for helpful comments. The ideas, methodology, and findings expressed in this paper remain our sole responsibility.

\section{References}

Aktas, N., De Bodt, E., Cousin, J. G., 2011. Do financial markets care about SRI? Evidence from mergers and acquisitions. Journal of Banking and Finance 35, 1753-1761.

Arouri, M., Pijourlet, G., 2017. CSR Performance and the value of cash holdings: International evidence. Journal of Business Ethics 140(2), 263-284.

Baker, M., Savasoglu, S., 2002. Limited arbitrage in mergers and acquisitions. Journal of Financial Economics 64, 91-115.

Barnea, A., Rubin, A., 2010. Corporate social responsibility as a conflict between shareholders. Journal of Business Ethics 97, 71-86.

Barney, J. B., Hansen, M. H., 1994. Trustworthiness as a source of competitive advantage. Strategic Management Journal 15, 175-190.

Bereskin, F. L., Byun, S. K., Officer, M. S., Oh, J. M., 2018. The effect of cultural similarity on mergers and acquisitions: Evidence from corporate social responsibility. Journal of Financial and Quantitative Analysis, Forthcoming.

Billett, M.T., Qian, Y., 2008. Are overconfident managers born or made? Evidence of selfattribution bias from frequent acquirers. Management Science 54, 1037-1051.

Boone, A., Uysal, V.B., 2018. Reputational concerns in the market for corporate control. Journal of Corporate Finance, Forthcoming.

Branch, B.S., Wang, J., 2008. Risk-arbitrage spreads and performance of risk arbitrage. The Journal of Alternative Investments 11, 9-22.

Branco, M.C., Rodrigues, L.L., 2006. Corporate social responsibility and resource-based perspectives. Journal of Business Ethics 69, 111-132.

Buchanan, B., Cao, C.X., Chen, C., 2018. Corporate social responsibility, firm value, and influential institutional ownership. Journal of Corporate Finance 52, 73-95. 
Buehlmaier, M.M.M., Zechner, J. 2017. Financial media, price discovery, and merger arbitrage. Working paper. Available at SSRN: https://ssrn.com/abstract=2858999.

Burns, D.J., Collett, N., 2017.A Stakeholder Framework for Evaluating the Impact of Mergers and Acquisitions. In Cary L. Cooper, Sydney Finkelstein (ed.) Advances in Mergers and Acquisitions(16), Emerald Publishing Limited.

Campbell, J.L. 2007. Why would corporations behave in socially responsible ways? An institutional theory of corporate social responsibility. Academy of Management Review 32, 946-967.

Cheng, B., Ioannou, I., Serafeim, G., 2014. Corporate social responsibility and access to finance. Strategic Management Journal 35, 1-23.

Cheung, A.W.K., 2016. Corporate social responsibility and corporate cash holdings. Journal of Corporate Finance 37(C), 412-430.

Coase, R.H., 1937. The nature of the firm. Econometrica 4, 386-405.

Cornelli, F., Li, D., 2001. Risk arbitrage in takeovers. Review of Financial Studies 15, 837- 868.

Cornell, B., Shapiro, A.C., 1987. Corporate stakeholder and corporate finance. Financial Management 16, 5-14.

Cumming, D.J., Ji, S., Johan, S., Tarsalewska, M., 2016. Manipulation and M\&As. Working paper. Available at: http://www.fmaconferences.org/Vegas/Papers/cjjt.pdf.

Cragg, J.G., Donald, S.G., 1993. Testing identifiability and specification in instrumental variable models. Econometric Theory 9, 222-240.

Deng, X., Kang, J.K., Low, B.S., 2013. Corporate social responsibility and stakeholder value maximization: Evidence from mergers. Journal of Financial Economics 110, 87-109.

Dhaliwal, D., Li, O.Z., Tsang, A., Yang, Y.G., 2014. Corporate social responsibility disclosure and the cost of equity capital: The roles of stakeholder orientation and financial transparency. Journal of Accounting and Public Policy 33, 328-355.

Diemont, D., Moore, K., Soppe, A., 2016. The downside of being responsible: corporate social responsibility and tail risk. Journal of Business Ethics 137, 213-229.

Donaldson T., Preston L.E., 1995. The stakeholder theory of the corporation: Concepts, evidence, and implications. Academy of Management Review 20, 65-91.

El Ghoul, S., Guedhami, O., Kwok, C.C., Mishra, D.R., 2011. Does corporate social responsibility affect the cost of capital? Journal of Banking and Finance 35, 2388-2406. 
Fama, E.F., Jensen, M.C., 1983. Separation of Ownership and Control. Journal of Law and Economics 26(2), 301-325.

Fauver, L., McDonald, M.B., Taboada, A.G., 2018. Does it pay to treat employees well? International evidence on the value of employee-friendly culture. Journal of Corporate Finance 50, 84-108.

Ferrell, A., Liang, H., Renneboog, L., 2016. Socially responsible firms. Journal of Financial Economics 122(3), 585-606.

Fombrun, C. J., Gardberg, N. A., Barnett, M. L., 2000. Opportunity platforms and safety nets: Corporate citizenship and reputational risk. Business and Society Review 105, 85-106.

Fransen, L., 2013. The embeddedness of responsible business practice: Exploring the interaction between national-institutional environments and corporate social responsibility. Journal of Business Ethics, 115(2), 213-227.

Freeman, R.E., 1984. Strategic management: A stakeholder approach, Marshfield, Pitman.

Friedman, M., 1970. The Social Responsibility of Business is to Increase its Profits. The NewYork Times Magazine, Sept-70, 32-33.

Gao, L., Zhang, J.H., 2015. Firms' earnings smoothing, corporate social responsibility, and valuation. Journal of Corporate Finance 32, 108-127.

Ghaly, M., Dang, V.A., Stathopoulos, K., 2015. Cash holdings and employee welfare. Journal of Corporate Finance 33, 53-70.

Gomes, M., Marsat, S., 2018. Does CSR impact premiums in M\&A transactions?. Finance Research Letters 26, 71-80.

Goss, A., Roberts, G.S., 2011. The impact of corporate social responsibility on the cost of bank loans. Journal of Banking and Finance 35(7), 1794-1810.

Hawn, O., 2013. How social legitimacy helps overcome low home country legitimacy: Corporate social responsibility and emerging market multinationals. Paper presented at the 2013 Academy of Management annual meeting, Orlando, Florida.

Hoffmeister, J., Dyl, E., 1981. Predicting outcomes of cash tender offers. Financial Management 10, 50-58.

Hong, H., Liskovich, I., 2015. Crime, punishment and the halo effect of corporate social responsibility Working paper 21215. National Bureau of Economic Research. Available at: http://www.nber.org/papers/w21215

Ioannou, I., Serafeim, G., 2012. What drives corporate social performance? The role of nationlevel institutions. Journal of International Business Studies 43, 834-864. 
Jensen, M.C., 2001. Value maximization, stakeholder theory, and the corporate objective function. Journal of Applied Corporate Finance 14, 8-21.

Jetley, G., Ji, X., 2010. The shrinking merger arbitrage spread: Reasons and implications. Financial Analysts Journal 66, 54-68.

Jennings, R., Mazzeo, M.A., 1993. Competing bids, target management resistance and the structure of takeover bids. Review of Financial Studies, 6, 883-909.

Jiao, Y., 2010. Stakeholder welfare and firm value. Journal of Banking and Finance 34, 25492561.

Jindra, J., Walkling R.A., 2004. Speculation spreads and the market pricing of proposed acquisitions. Journal of Corporate Finance 10, 495-526.

Jorion, P., Goetzmann, W. N., 1999. Global stock markets in the twentieth century. The Journal of Finance 54(3), 953-980.

Kim, Y., Li, H., Li, S., 2014. Corporate social responsibility and stock price crash risk. Journal of Banking and Finance 43, 1-13.

King, A., Bartels, W., 2015. KPMG Survey of Corporate Responsibility Reporting 2015.

Kristoffersen, I., Gerrans, P., Clark-Murphy, M., 2005. The corporate social responsibility and the theory of the firm. Finance and Economics \& FIMARC Working Paper Series, Edith Cowan University.

Lakonishok, J., Vermaelen, T., 1990. Anomalous price behavior around repurchase tender offers. Journal of Finance 45, 455-477.

Lang, L., Stulz, R.M., Walkling, R.A., 1989. Managerial performance, Tobin's q, and the gain from successful tender offers. Journal of Financial Economics 24, 137-154.

Larcker, D.F., Lys, T., 1987. An empirical analysis of the incentives to engage in costly information acquisition: The case of risk arbitrage. Journal of Financial Economics 18, 111126.

Levitt, T., 1958. The dangers of social responsibility. Harvard Business Review 36, 41-50.

Lee, K.H., Mauer, D.C., Xu, Q.E., 2018. Human capital relatedness and mergers and acquisitions. Journal of Financial Economics, Forthcoming. Doi: 10.1016/j.jfineco.2018.03.008

Liang, H., Renneboog, L., 2017. On the Foundations of Corporate Social Responsibility. The Journal of Finance 72(2), 853-910. 
Liang, H., Renneboog, L., Vansteenkiste, C., 2017. Corporate employee-engagement and merger outcomes. Working paper. Available at SSRN: https://ssrn.com/abstract=2926479.

Lins, K.V., Servaes, H., Tamayo, A., 2017. Social capital, trust, and firm performance: The value of corporate social responsibility during the financial crisis. The Journal of Finance 72(4), 1785-1824.

Martínez-Ferrero, J., Banerjee, S., García-Sánchez, I.M., 2016. Corporate social responsibility as a strategic shield against costs of earnings management practices. Journal of Business Ethics 133, 305-324.

Masulis, R., Wang, C., Xie, F., 2016. Employee-manager alliances and shareholder returns from acquisitions. Working paper.

Available at SSRN: https://papers.ssrn.com/sol3/papers.cfm?abstract id=2895745.

Miles, S., 2012. Stakeholder: Essentially contested or just confused? Journal of Business Ethics 108, 285-298.

Mitchell, M., Pulvino T., 2001. Characteristics of risk and return in risk arbitrage. Journal of Finance 56, 2135-2175.

$\mathrm{Ng}$, A.C., Rezaee, Z., 2015. Business sustainability performance and cost of equity capital. Journal of Corporate Finance 34, 128-149.

Oikonomou, I., Brooks, C., Pavelin, S., 2014. The effects of corporate social performance on the cost of corporate debt and credit ratings. Financial Review 49(1), 49-75.

Parker, V.R., 2005. Managing Hedge Fund Risk: Strategies and Insights from Investors, Counterparties, Hedge Funds and Regulators. Risk Books; 2nd edition.

Porter, M.E., Kramer, M.R., 2006. The link between competitive advantage and corporate social responsibility. Harvard Business Review 12, 78-92.

Ramsey, J.B., 1969. Tests for specification errors in classical linear least-squares regression analysis. Journal of the Royal Statistical Society, Series B (Methodological), 350-371.

Rhodes-Kropf, M., Robinson, D.T., 2008. The market for mergers and the boundaries of the firm. Journal of Finance 63, 1169-1211.

Sargan, J.D., 1958. The estimation of economic relationships with instrumental variables. Econometrica 26, 393-415.

Schreck, P., 2011. Reviewing the business case for corporate social responsibility: New evidence and analysis. Journal of Business Ethics 103(2), 167-188.

Servaes, H., Tamayo, A. (2013). The impact of corporate social responsibility on firm value: The role of customer awareness. Management science 59(5), 1045-1061. 
Shah, R.H., Swaminathan, V., 2008. Factors influencing partner selection in strategic alliances: The moderating role of alliance context. Strategic Management Journal 29, 471-494.

Shane, P.B., Spicer, B.H., 1983. Market response to environmental information produced outside the firm. The Accounting Review 58, 521-538.

Shleifer, A., Summers, L.H., 1988. "Breach of trust in hostile takeovers," in Alan J. Auerbach (eds.), Corporate takeovers: Causes and consequences. Chicago: The University of Chicago Press.

Sun, X., Gunia, B.C., 2018. Economic resources and corporate social responsibility. Journal of Corporate Finance 51, 332-351.

Stellner, C., Klein, C., Zwergel, B., 2015. Corporate social responsibility and Eurozone corporate bonds: The moderating role of country sustainability. Journal of Banking and Finance 59, 538-549.

Teoh, S.H., Welch I., Wazzan, C.P., 1999. The effect of socially activist investment policies on the financial markets: evidence from the South African boycott. Journal of Business 72, 3589.

Walkling, R., 1985. Predicting tender offer success: A logistic analysis, Journal of Financial and Quantitative Analysis 20(4), 461-478.

Withisuphakorn, P., Jiraporn, P., 2016. The effect of firm maturity on corporate social responsibility (CSR): do older firms invest more in CSR?. Applied Economics Letters 23(4), 298301. 


\section{Appendix}

\section{Table A1: Description of variables}

\begin{tabular}{|c|c|c|}
\hline Variable & Description & Expected sign \\
\hline ArbSpread & $\begin{array}{l}\text { Arbitrage spread one day after announcement. It is computed for cash and stock deals as } \\
\text { per equations } 1 \text { and } 2 \text {, respectively. }\end{array}$ & \\
\hline Bid premium & $\begin{array}{l}\text { Following Jindra and Walkling (2004), we compute the bid premium as follows: Bid premium } \\
=\text { (offer price - average price before bid) / average price before bid. Average price before bid } \\
\text { is computed from } t-30 \text { to } t-10 \text { relative to the announcement date. }\end{array}$ & + \\
\hline CumRet & $\begin{array}{l}\text { Following Jindra and Walkling }(2004) \text {, we measure cumulative return as the target's stock } \\
\text { price return from } t-42 \text { to } t-1 \text { relative to announcement date. }\end{array}$ & - \\
\hline \multirow[t]{3}{*}{ AbnVol } & $\begin{array}{l}\text { Cumulative abnormal trading volume around acquisition announcements using Lakonishok } \\
\text { and Vermaelen's method (1990): }\end{array}$ & - \\
\hline & AbnVol $=\sum_{t=t-1}^{t+1} \frac{\text { Volume }_{t}}{\text { Normal volume }}$ & \\
\hline & $\begin{array}{l}\text { where normal volume is the average trading volume between } t-50 \text { and } t-25 \text { relative to } \\
\text { announcement date. }\end{array}$ & \\
\hline TarSize & Natural logarithm of target's market value & + \\
\hline AcqSize & Natural logarithm of acquirer's market value & - \\
\hline TarMTB & Market-to-Book ratio of the target. & - \\
\hline AcqQ & Tobin's Q of the acquirer. & - \\
\hline AcqAR & $\begin{array}{l}\text { Acquirer's buy-and-hold abnormal return estimated using } 200 \text { trading days of return data } \\
\text { ending } 11 \text { before deal announcement (as in Deng et al., 2013). Given our international } \\
\text { dataset, the market return used is the return on the primary stock market of the country in } \\
\text { which the firm's headquarter is located (as in Liang et al., 2017). }\end{array}$ & - \\
\hline AcqROA & Return on asset of the acquirer. & $+/-$ \\
\hline AcqCAPEX & Acquirer's capital expenditures scaled by total assets. & $+/-$ \\
\hline AcqCF & Acquirer's cash flow (FFO) scaled by total assets. & $+/-$ \\
\hline AcqLev & Acquirer's debt-to-total assets ratio. & $+/-$ \\
\hline AcqRD & Acquirer's research and development expenses scaled by total assets. & $+/-$ \\
\hline AcqAdv & Acquirer's advertising expenses (from Factset) scaled by total assets. & $+/-$ \\
\hline AcqAge & Acquiring firm's age & $+/-$ \\
\hline Cash & $\begin{array}{l}\text { Dummy variable that takes the value of one when the form of consideration is cash-only, } \\
\text { and zero otherwise. }\end{array}$ & - \\
\hline Hostile & $\begin{array}{l}\text { Dummy variable that takes the value of one when the takeover attempt is considered } \\
\text { hostile, and zero otherwise. }\end{array}$ & $+/-$ \\
\hline Cross border & $\begin{array}{l}\text { Dummy variable that takes the value of one when the deal involves a target and an acquirer } \\
\text { coming from two different countries, and zero otherwise. }\end{array}$ & + \\
\hline Diversifying & $\begin{array}{l}\text { Dummy variable that takes the value of one if the acquirer and the target have different } \\
\text { first two-digit standard industrial classification codes and zero otherwise. }\end{array}$ & + \\
\hline Toehold & $\begin{array}{l}\text { Dummy variable that takes a value of one if the acquirer holds at least } 5 \% \text { of the target } \\
\text { shares prior to the announcement and zero otherwise. }\end{array}$ & - \\
\hline Multiple bids & $\begin{array}{l}\text { Dummy variable that takes a value of one if there is more than one acquirer and zero } \\
\text { otherwise. }\end{array}$ & - \\
\hline
\end{tabular}


Table 1: Average speculation spreads over the sample period

\begin{tabular}{|c|c|c|c|c|c|c|c|}
\hline Year & $\begin{array}{l}\text { Number of } \\
\text { deal offers }\end{array}$ & $\begin{array}{c}\text { Average } \\
\text { arbitrage spread } \\
\text { (\%) }\end{array}$ & $\begin{array}{c}\% \text { of cases with negative } \\
\text { arbitrage spreads }\end{array}$ & $\begin{array}{c}\text { Number of } \\
\text { successful } \\
\text { deals }\end{array}$ & $\begin{array}{l}\text { Number of } \\
\text { cash deals }\end{array}$ & $\begin{array}{l}\text { Number of } \\
\text { hostile deals }\end{array}$ & $\begin{array}{c}\text { Number of cross- } \\
\text { border deals }\end{array}$ \\
\hline 2004 & 6 & 10.90 & 16.67 & 1 & 1 & 1 & 1 \\
\hline 2005 & 9 & 2.88 & 11.11 & 7 & 5 & 0 & 4 \\
\hline 2006 & 36 & 3.28 & 30.56 & 26 & 21 & 4 & 16 \\
\hline 2007 & 40 & 3.24 & 37.50 & 30 & 24 & 4 & 25 \\
\hline 2008 & 39 & 5.14 & 23.08 & 25 & 25 & 5 & 18 \\
\hline 2009 & 28 & 4.89 & 21.43 & 21 & 15 & 2 & 11 \\
\hline 2010 & 63 & 2.34 & 38.10 & 48 & 33 & 3 & 27 \\
\hline 2011 & 68 & 3.61 & 29.41 & 56 & 47 & 4 & 25 \\
\hline 2012 & 84 & 4.43 & 15.48 & 68 & 54 & 1 & 33 \\
\hline 2013 & 64 & 3.94 & 23.44 & 49 & 40 & 0 & 21 \\
\hline 2014 & 88 & 3.28 & 25.00 & 65 & 50 & 2 & 35 \\
\hline 2015 & 152 & 4.50 & 20.39 & 104 & 74 & 17 & 54 \\
\hline 2016 & 49 & 2.62 & 20.41 & 28 & 28 & 4 & 16 \\
\hline Total & 726 & 3.73 & 24.93 & 529 & 417 & 47 & 286 \\
\hline
\end{tabular}

Table 1 reports average arbitrage spreads and number of deal offers over the sample period. See Equations (1) and (2) for the calculation of the arbitrage spread. Our sample includes 726 deal offers announced between January 1, 2004, and December 31, 2016. Arbitrage spreads are computed one day after deal announcement. 
Table 2: Deal offers by acquirer and target countries

\begin{tabular}{|c|c|c|c|c|c|c|c|c|c|c|c|c|c|}
\hline \multicolumn{7}{|c|}{ Acquirer } & \multicolumn{7}{|c|}{ Target } \\
\hline & \multicolumn{2}{|c|}{ Domestic deals } & \multicolumn{2}{|c|}{$\begin{array}{l}\text { Cross-border } \\
\text { deals }\end{array}$} & \multicolumn{2}{|c|}{ All deals } & & \multicolumn{2}{|c|}{ Domestic deals } & \multicolumn{2}{|c|}{$\begin{array}{c}\text { Cross-border } \\
\text { deals }\end{array}$} & \multicolumn{2}{|c|}{ All deals } \\
\hline & $\#$ & $\begin{array}{l}\text { Value } \\
\text { (US\$M) }\end{array}$ & $\#$ & $\begin{array}{l}\text { Value } \\
\text { (US\$M) }\end{array}$ & $\#$ & $\begin{array}{l}\text { Value } \\
\text { (US\$M) }\end{array}$ & & $\#$ & $\begin{array}{l}\text { Value } \\
\text { (US\$M) }\end{array}$ & $\#$ & $\begin{array}{l}\text { Value } \\
\text { (US\$M) }\end{array}$ & \# & $\begin{array}{l}\text { Value } \\
\text { (US\$M) }\end{array}$ \\
\hline USA & 237 & $2,048,496$ & 57 & 388,791 & 294 & $2,437,287$ & USA & 237 & $2,048,496$ & 88 & 598,475 & 325 & $2,646,970$ \\
\hline Canada & 41 & 61,768 & 27 & 131,666 & 68 & 193,435 & Australia & 49 & 80,546 & 35 & 76,904 & 84 & 157,450 \\
\hline UK & 24 & 77,719 & 43 & 349,085 & 67 & 426,804 & Canada & 41 & 61,768 & 31 & 111,584 & 72 & 173,352 \\
\hline Australia & 49 & 80,546 & 6 & 147,598 & 55 & 228,143 & UK & 24 & 77,719 & 39 & 423,701 & 63 & 501,420 \\
\hline Japan & 27 & 77,115 & 27 & 60,472 & 54 & 137,588 & Japan & 27 & 77,115 & 2 & 17,234 & 29 & 94,350 \\
\hline France & 10 & 12,629 & 21 & 186,019 & 28 & 198,648 & France & 10 & 12,629 & 7 & 23,108 & 17 & 35,737 \\
\hline Germany & 7 & 62,678 & 17 & 109,898 & 24 & 172,575 & South Africa & 9 & 3,422 & 3 & 4,183 & 12 & 7,605 \\
\hline Switzerland & 5 & 67,400 & 13 & 56,193 & 18 & 123,593 & Switzerland & 5 & 67,400 & 7 & 62,194 & 12 & 129,593 \\
\hline Spain & 3 & 3,109 & 13 & 63,011 & 16 & 66,120 & Netherlands & 2 & 7,624 & 9 & 137,087 & 11 & 144,712 \\
\hline South Africa & 9 & 3,422 & 2 & 2,309 & 11 & 5,732 & Germany & 7 & 62,678 & 2 & 9,488 & 9 & 72,166 \\
\hline Netherlands & 2 & 7,624 & 7 & 40,514 & 9 & 48,138 & Sweden & 1 & 60 & 8 & 56,864 & 9 & 56,923 \\
\hline China & 0 & 0 & 8 & 12,798 & 8 & 12,798 & Italy & 3 & 67,250 & 4 & 11,773 & 7 & 79,022 \\
\hline Ireland & 0 & 0 & 7 & 48,768 & 7 & 48,768 & Spain & 3 & 3,109 & 4 & 27,150 & 7 & 30,259 \\
\hline Italy & 3 & 67,250 & 3 & 14,007 & 6 & 81,257 & Ireland & 0 & 0 & 6 & 105,426 & 6 & 105,426 \\
\hline Hong Kong & 2 & 7,396 & 3 & 5,405 & 5 & 12,800 & Israel & 0 & 0 & 5 & 2,833 & 5 & 2,833 \\
\hline India & 2 & 4,006 & 3 & 1,400 & 5 & 5,405 & South Korea & 3 & 7,916 & 2 & 6,504 & 5 & 14,420 \\
\hline Norway & 2 & 1,741 & 3 & 4,648 & 5 & 6,389 & India & 2 & 4,006 & 2 & 3,600 & 4 & 7,606 \\
\hline South Korea & 3 & 7,916 & 2 & 13,891 & 5 & 21,809 & Norway & 2 & 1,741 & 2 & 4,650 & 4 & 6,391 \\
\hline Singapore & 0 & 0 & 4 & 13,373 & 4 & 13,373 & Taiwan & 4 & 3,356 & 0 & 0 & 4 & 3,356 \\
\hline Taiwan & 4 & 3,356 & 0 & 0 & 4 & 3,356 & Brazil & 1 & 1,143 & 2 & 4,149 & 3 & 5,292 \\
\hline Brazil & 1 & 1,143 & 2 & 10,540 & 3 & 11,683 & Hong Kong & 2 & 7,396 & 1 & 1,472 & 3 & 8,868 \\
\hline Other (15) & 9 & 27,147 & 18 & 109,918 & 19 & 137,066 & Other (22) & 8 & 27,088 & 27 & 81,925 & 35 & 109,012 \\
\hline Total & 440 & $2,622,462$ & 286 & $1,770,302$ & 726 & $4,392,764$ & & 440 & $2,622,462$ & 286 & $1,770,302$ & 726 & $4,392,764$ \\
\hline
\end{tabular}

Table 2 reports descriptive statistics on all attempted domestic and cross-border deals along with information on deal values. The deal offers are listed by country of origin of the target and acquirer. The data are obtained from the SDC database. Reported values are denominated in US dollars (not adjusted for inflation). \# indicates the number of deals. 
Table 3: Summary statistics

\begin{tabular}{|c|c|c|c|c|c|c|}
\hline & Observations & Mean & Q1 & Median & Q3 & $\begin{array}{l}\text { Standard } \\
\text { Deviation }\end{array}$ \\
\hline ArbSpread & 726 & 0.037 & 0.001 & 0.022 & 0.071 & 0.080 \\
\hline AcqCSR & 726 & 0.599 & 0.391 & 0.635 & 0.821 & 0.240 \\
\hline AcqENV & 726 & 0.577 & 0.234 & 0.667 & 0.905 & 0.323 \\
\hline AcqSOC & 726 & 0.587 & 0.290 & 0.662 & 0.877 & 0.308 \\
\hline AcqGOV & 726 & 0.633 & 0.450 & 0.723 & 0.855 & 0.267 \\
\hline BidPremium & 726 & 0.343 & 0.175 & 0.300 & 0.455 & 0.329 \\
\hline CumRet & 726 & 0.080 & -0.030 & 0.060 & 0.175 & 0.208 \\
\hline AbnVol & 726 & 24.513 & 3.430 & 14.603 & 39.796 & 67.942 \\
\hline TarSize & 726 & 7.085 & 5.857 & 7.236 & 8.351 & 1.854 \\
\hline AcqSize & 726 & 9.210 & 8.162 & 9.172 & 10.310 & 1.467 \\
\hline TarMTB & 726 & 2.037 & 1.152 & 1.915 & 3.255 & 15.849 \\
\hline AcqQ & 726 & 1.755 & 1.267 & 1.700 & 1.896 & 0.767 \\
\hline AcqAR & 726 & 0.147 & -0.055 & 0.001 & 0.156 & 1.925 \\
\hline AcqROA & 726 & 0.062 & 0.022 & 0.059 & 0.099 & 0.084 \\
\hline AcqCAPEX & 726 & 0.043 & 0.010 & 0.026 & 0.055 & 0.059 \\
\hline AcqCF & 726 & 0.102 & 0.050 & 0.096 & 0.139 & 0.082 \\
\hline AcqLev & 726 & 0.240 & 0.108 & 0.215 & 0.343 & 0.175 \\
\hline AcqRD & 726 & 0.021 & 0.000 & 0.000 & 0.024 & 0.043 \\
\hline AcqAdv & 726 & 0.002 & 0.000 & 0.000 & 0.000 & 0.014 \\
\hline AcqAge & 726 & 55.844 & 22.000 & 38.000 & 79.000 & 48.842 \\
\hline Cash & 726 & 0.574 & 0.000 & 1.000 & 1.000 & 0.495 \\
\hline Hostile & 726 & 0.065 & 0.000 & 0.000 & 0.000 & 0.246 \\
\hline Cross border & 726 & 0.394 & 0.000 & 0.000 & 1.000 & 0.489 \\
\hline Diversifying & 726 & 0.186 & 0.000 & 0.000 & 0.000 & 0.389 \\
\hline Toehold & 726 & 0.081 & 0.000 & 0.000 & 0.000 & 0.273 \\
\hline Multiple bids & 726 & 0.103 & 0.000 & 0.000 & 0.000 & 0.305 \\
\hline
\end{tabular}

Table 3 reports summary statistics for our sample. The sample consists of 726 deal offers initiated between January 1, 2004 and December 31, 2016. ArbSpread represents the arbitrage spreads one day after announcement. See Equations (1) and (2) for the calculation of the arbitrage spread. AcqCSR is the acquirer's overall CSR score. AcqENV is an environmental score. AcqSOC is a social score. AcqGOV is a governance score. BidPremium is the percentage difference between the offer price and the target's average price between $\mathrm{t}-30$ to $\mathrm{t}-10$ relative to announcement date. CumRet is the cumulative target's stock price return from $\mathrm{t}-42$ to $\mathrm{t}-1$ relative to announcement date. AbnVol is abnormal trading volume around acquisition announcements (from t-1 to t+1). AcqSize is the acquirer's market value. TarSize is the target's market value. TarMTB is the targets' market-to-book ratio. AcqQ is the acquirers' Tobin's Q. AcqAR is the acquirers' market-adjusted return. AcqROA is the acquirer's return on asset. AcqCAPEX represents the acquirer's capital expenditures scaled by total assets. AcqCF is the acquirer's cash flow scaled by total assets. AcqLev is the acquirer's debt-to-asset ratio. AcqRD is the acquirer's research and development expenses scaled by total assets. AcqAdv is the acquirer's advertising expenses scaled by total assets. AcqAge is the acquiring firm's age. Cash is a dummy variable that takes a value of one for purely cash-financed deals, and zero otherwise. Hostile is a dummy variable that takes a value of one for hostile bids, and zero otherwise. Cross border is a dummy variable that takes a value of one when the acquirer and the target are not in the same country, and zero otherwise. Diversifying is a dummy variable that takes the value of one if the acquirer and the target have different first two-digit standard industrial classification codes and zero otherwise. Toehold is a dummy variable that takes a value of one if the acquirer holds at least $5 \%$ of the target shares prior to the announcement and zero otherwise. Multiple bids is a dummy variable that takes a value of one if there is more than one acquirer and zero otherwise. All financial variables are winsorized at the $1 \%$ and $99 \%$ level. 


\section{Table 4: Correlation matrix}

\begin{tabular}{|c|c|c|c|c|c|c|c|c|c|c|c|c|c|c|c|c|c|c|c|c|c|c|c|c|c|c|c|}
\hline & & 1 & 2 & 3 & 4 & 5 & 6 & 7 & 8 & 9 & 10 & 11 & 12 & 13 & 14 & 15 & 16 & 17 & 18 & 19 & 20 & 21 & 22 & 23 & 24 & 25 & 26 \\
\hline 1 & ArbSpread & 1.000 & & & & & & & & & & & & & & & & & & & & & & & & & \\
\hline 2 & AcqCSR & -0.136 & 1.000 & & & & & & & & & & & & & & & & & & & & & & & & \\
\hline 3 & AcqENV & -0.135 & 0.888 & 1.000 & & & & & & & & & & & & & & & & & & & & & & & \\
\hline 4 & AcgSOC & -0.115 & 0.906 & 0.844 & 1.000 & & & & & & & & & & & & & & & & & & & & & & \\
\hline 5 & AcqGov & -0.070 & 0.581 & 0.214 & 0.272 & 1.000 & & & & & & & & & & & & & & & & & & & & & \\
\hline 6 & Bid premium & 0.169 & 0.042 & 0.030 & 0.046 & 0.020 & 1.000 & & & & & & & & & & & & & & & & & & & & \\
\hline 7 & CumRet & -0.150 & 0.004 & 0.039 & -0.004 & -0.034 & 0.189 & 1.000 & & & & & & & & & & & & & & & & & & & \\
\hline 8 & AbnVol (x100) & -0.071 & 0.122 & 0.092 & 0.098 & 0.106 & 0.256 & 0.007 & 1.000 & & & & & & & & & & & & & & & & & & \\
\hline 9 & Acasize & -0.133 & 0.407 & 0.390 & 0.400 & 0.202 & -0.033 & 0.053 & -0.017 & 1.000 & & & & & & & & & & & & & & & & & \\
\hline 10 & Tarsize & 0.053 & 0.236 & 0.196 & 0.215 & 0.154 & -0.350 & -0.071 & -0.151 & 0.381 & 1.000 & & & & & & & & & & & & & & & & \\
\hline 11 & TarMTB & 0.068 & 0.010 & -0.007 & 0.012 & 0.023 & 0.021 & 0.012 & -0.056 & 0.078 & 0.042 & 1.000 & & & & & & & & & & & & & & & \\
\hline 12 & Acqa & 0.044 & -0.032 & -0.110 & -0.058 & 0.115 & 0.121 & 0.026 & -0.027 & 0.148 & 0.060 & 0.151 & 1.000 & & & & & & & & & & & & & & \\
\hline 13 & AcGAR & -0.020 & -0.038 & -0.033 & -0.015 & -0.046 & -0.084 & 0.146 & -0.088 & -0.037 & 0.027 & 0.068 & 0.007 & 1.000 & & & & & & & & & & & & & \\
\hline 14 & AcgROA & 0.024 & 0.107 & 0.103 & 0.096 & 0.056 & 0.077 & 0.032 & 0.048 & 0.244 & 0.207 & 0.088 & 0.381 & -0.082 & 1.000 & & & & & & & & & & & & \\
\hline 15 & AcqCAPEX & 0.089 & -0.009 & -0.014 & -0.033 & 0.034 & 0.101 & 0.026 & 0.008 & -0.211 & -0.127 & -0.036 & 0.051 & -0.017 & 0.077 & 1.000 & & & & & & & & & & & \\
\hline 16 & AcqCF & 0.066 & 0.159 & 0.109 & 0.121 & 0.160 & 0.182 & 0.023 & 0.046 & 0.092 & 0.028 & 0.089 & 0.449 & -0.044 & 0.405 & 0.347 & 1.000 & & & & & & & & & & \\
\hline 17 & Acqlev & -0.045 & 0.051 & 0.068 & 0.041 & 0.010 & -0.211 & -0.111 & -0.043 & 0.029 & 0.136 & 0.044 & -0.147 & 0.099 & -0.139 & 0.005 & -0.179 & 1.000 & & & & & & & & & \\
\hline 18 & AcqRD & -0.039 & 0.079 & 0.085 & 0.090 & 0.006 & 0.102 & 0.093 & -0.015 & 0.127 & 0.017 & 0.147 & 0.433 & 0.028 & 0.200 & -0.120 & 0.325 & -0.170 & 1.000 & & & & & & & & \\
\hline 19 & AcaAdv & -0.022 & -0.011 & 0.093 & 0.052 & -0.201 & 0.021 & -0.018 & 0.042 & 0.024 & 0.011 & -0.023 & -0.015 & -0.018 & 0.020 & 0.018 & 0.032 & -0.086 & 0.081 & 1.000 & & & & & & & \\
\hline 20 & AcaAge & -0.054 & 0.349 & 0.373 & 0.382 & 0.085 & 0.014 & 0.000 & 0.102 & 0.301 & 0.156 & -0.046 & -0.118 & -0.010 & 0.019 & -0.136 & -0.033 & 0.041 & 0.045 & 0.102 & 1.000 & & & & & & \\
\hline 21 & Cash & -0.247 & 0.167 & 0.245 & 0.200 & -0.077 & 0.211 & 0.109 & 0.227 & 0.225 & -0.245 & -0.008 & 0.054 & 0.036 & 0.071 & -0.088 & 0.106 & -0.043 & 0.132 & 0.075 & 0.148 & 1.000 & & & & & \\
\hline 22 & Hostile & -0.062 & -0.031 & -0.036 & -0.038 & 0.003 & -0.086 & -0.006 & -0.089 & -0.005 & 0.076 & -0.022 & 0.018 & 0.034 & 0.001 & -0.033 & -0.043 & 0.072 & -0.013 & -0.019 & -0.015 & -0.023 & 1.000 & & & & \\
\hline 23 & Cross border & -0.083 & 0.153 & 0.226 & 0.212 & -0.104 & 0.071 & 0.082 & 0.054 & 0.193 & 0.079 & 0.010 & 0.029 & 0.041 & 0.114 & -0.051 & 0.056 & -0.055 & 0.047 & 0.084 & 0.159 & 0.238 & 0.074 & 1.000 & & & \\
\hline 24 & Diversifying & -0.039 & 0.039 & 0.045 & 0.050 & -0.007 & -0.020 & 0.002 & 0.037 & -0.018 & -0.023 & 0.004 & -0.014 & -0.069 & -0.047 & -0.083 & -0.082 & 0.059 & 0.008 & -0.061 & 0.030 & 0.025 & 0.018 & 0.035 & 1.000 & & \\
\hline 25 & Toehold & -0.078 & -0.006 & 0.035 & 0.000 & -0.059 & -0.088 & -0.050 & -0.026 & -0.023 & -0.072 & -0.058 & -0.078 & 0.006 & -0.020 & 0.054 & -0.053 & 0.053 & -0.079 & -0.008 & 0.018 & 0.011 & 0.127 & 0.059 & 0.013 & 1.000 & \\
\hline 26 & Multiple bids & -0.118 & -0.032 & -0.060 & -0.048 & 0.041 & -0.074 & 0.148 & -0.029 & -0.067 & -0.007 & -0.056 & 0.076 & 0.048 & 0.078 & 0.020 & 0.051 & -0.031 & -0.015 & -0.030 & -0.007 & 0.036 & 0.131 & 0.032 & -0.011 & 0.048 & \\
\hline
\end{tabular}

Table 4 reports correlation coefficients between variables for our sample. ArbSpread represents the arbitrage spreads one day after announcement. See Equations (1) and (2) for the calculation of the arbitrage spread. AcqCSR is acquirers' last available CSR score before announcement. AcqENV is an environmental score. AcqSOC is a social score. AcqGOV is a governance score. Bid premium is the percentage difference between the offer price and the target's average price between $t-30$ to $t-10$ relative to announcement date. CumRet is the cumulative target's stock price return from $t-42$ to $t-1$ relative to announcement date. AbnVol is abnormal trading volume around acquisition announcements (from $t-1$ to $t+1$ ). AcqSize is the acquirer's market value. TarSize is the target's market value. TarMTB is the targets' market-to-book ratio. AcqQ is the acquirers' Tobin's Q. AcqAR is the acquirers' market-adjusted return. AcqROA is the acquirer's return on asset. AcqCAPEX represents the acquirer's capital expenditures scaled by total assets. AcqCF is the acquirer's acquirers' Tobin's $\mathrm{Q}$. AcqAR is the acquirers' market-adjusted return. AcqROA is the acquirer's return on asset. AcqCAPEX represents the acquirer's capital expenditures scaled by total assets. AcqCF is the acquirer's
cash flow scaled by total assets. AcqLev is the acquirer's debt-to-asset ratio. AcqRD is the acquirer's research and development expenses scaled by total assets. AcqAdv is the acquirer's advertising expenses scaled by total assets. AcqAge is the acquiring firm's age. Cash is a dummy variable that takes a value of one for purely cash-financed deals, and zero otherwise. Hostile is a dummy variable that takes a value of one for hostile bids, and zero otherwise. Cross border is a dummy variable that takes a value of one when the acquirer and the target are not in the same country, and zero otherwise. Diversifying is a dummy variable that takes the value of one if the acquirer and the target have different first two-digit standard industrial classification codes and zero otherwise. Toehold is a dummy variable that takes a value of one if the acquirer holds at least $5 \%$ of the target shares prior to the announcement and zero otherwise. Multiple bids is a dummy variable that takes a value of one if there is more than one acquirer and zero otherwise. All financial variables are winsorized at the $1 \%$ and $99 \%$ level. Bold denoted significance at the $5 \%$ level or lower. 
Table 5: Acquirer's CSR and arbitrage spreads

\begin{tabular}{|c|c|c|c|c|}
\hline & \multicolumn{4}{|c|}{ Dependent variable: ArbSpread } \\
\hline & (1) & (2) & (3) & (4) \\
\hline & CSR & Environment & Social & Governance \\
\hline Constant & $\begin{array}{c}0.083^{* *} \\
(207)\end{array}$ & $\begin{array}{l}0.088^{* *} \\
(2.20)\end{array}$ & $\begin{array}{l}0.078^{*} \\
(1.92)\end{array}$ & $\begin{array}{c}0.098^{* *} \\
(2.48)\end{array}$ \\
\hline AcqCSR & $\begin{array}{c}-0.046 * * * \\
(-2.92)\end{array}$ & $\begin{array}{c}-0.026 * * \\
(-2.13)\end{array}$ & $\begin{array}{c}-0.030^{* *} \\
(-2.31)\end{array}$ & $\begin{array}{c}-0.028^{* *} \\
(-2.29)\end{array}$ \\
\hline Bid premium & $\begin{array}{c}0.082^{* * *} \\
(6.64)\end{array}$ & $\begin{array}{c}0.081^{* * *} \\
(6.56)\end{array}$ & $\begin{array}{c}0.082^{* * *} \\
(6.65)\end{array}$ & $\begin{array}{c}0.080 * * * \\
(6.50)\end{array}$ \\
\hline CumRet & $\begin{array}{c}-0.057 * * * \\
(-3.83)\end{array}$ & $\begin{array}{c}-0.055^{* * *} \\
(-3.69)\end{array}$ & $\begin{array}{c}-0.058^{* * *} \\
(-3.85)\end{array}$ & $\begin{array}{c}-0.056^{* * *} \\
(-3.74)\end{array}$ \\
\hline AbnVol $(\times 100)$ & $\begin{array}{l}-0.008 \\
(1.22)\end{array}$ & $\begin{array}{l}-0.009 \\
(-1.42)\end{array}$ & $\begin{array}{l}-0.009 \\
(-1.43)\end{array}$ & $\begin{array}{l}-0.008 \\
(-1.21)\end{array}$ \\
\hline AcqSize & $\begin{array}{c}-0.006^{* *} \\
(-2.09)\end{array}$ & $\begin{array}{c}-0.007 * * * \\
(-2.62)\end{array}$ & $\begin{array}{c}-0.007 * * \\
(-2.42)\end{array}$ & $\begin{array}{c}-0.008 * * * \\
(-3.17)\end{array}$ \\
\hline TarSize & $\begin{array}{c}0.008^{* * *} \\
(3.74)\end{array}$ & $\begin{array}{c}0.008 * * * \\
(3.69)\end{array}$ & $\begin{array}{c}0.008^{* * *} \\
(3.69)\end{array}$ & $\begin{array}{c}0.008^{* * *} \\
(3.60)\end{array}$ \\
\hline TarMTB & $\begin{array}{c}0.001^{* *} \\
(2.08)\end{array}$ & $\begin{array}{c}0.001^{* *} \\
(2.03)\end{array}$ & $\begin{array}{c}0.001 * * \\
(2.08)\end{array}$ & $\begin{array}{c}0.001^{* *} \\
(2.10)\end{array}$ \\
\hline AcqQ & $\begin{array}{l}0.002 \\
(0.52)\end{array}$ & $\begin{array}{l}0.002 \\
(0.50)\end{array}$ & $\begin{array}{l}0.003 \\
(0.60)\end{array}$ & $\begin{array}{l}0.005 \\
(1.07)\end{array}$ \\
\hline AcqAR & $\begin{array}{l}0.010 \\
(0.83)\end{array}$ & $\begin{array}{l}0.009 \\
(0.74)\end{array}$ & $\begin{array}{l}0.010 \\
(0.88)\end{array}$ & $\begin{array}{l}0.010 \\
(0.87)\end{array}$ \\
\hline AcqROA & $\begin{array}{l}-0.012 \\
(-0.20)\end{array}$ & $\begin{array}{l}-0.003 \\
(0.05)\end{array}$ & $\begin{array}{l}-0.005 \\
(-0.08)\end{array}$ & $\begin{array}{l}-0.005 \\
(-0.08)\end{array}$ \\
\hline AcqCAPEX & $\begin{array}{l}0.100 \\
(1.23)\end{array}$ & $\begin{array}{l}0.110 \\
(1.35)\end{array}$ & $\begin{array}{l}0.102 \\
(1.26)\end{array}$ & $\begin{array}{l}0.093 \\
(1.14)\end{array}$ \\
\hline AcqCF & $\begin{array}{l}0.093 \\
(1.22)\end{array}$ & $\begin{array}{l}0.073 \\
(0.97)\end{array}$ & $\begin{array}{l}0.080 \\
(1.06)\end{array}$ & $\begin{array}{l}0.071 \\
(0.95)\end{array}$ \\
\hline AcqLev & $\begin{array}{l}-0.001 \\
(-0.03)\end{array}$ & $\begin{array}{l}-0.001 \\
(-0.06)\end{array}$ & $\begin{array}{l}-0.002 \\
(-0.08)\end{array}$ & $\begin{array}{l}-0.003 \\
(-0.15)\end{array}$ \\
\hline AcqRD & $\begin{array}{l}-0.090 \\
(-0.89)\end{array}$ & $\begin{array}{l}-0.099 \\
(-0.97)\end{array}$ & $\begin{array}{l}-0.087 \\
(-0.85)\end{array}$ & $\begin{array}{l}-0.111 \\
(-1.10)\end{array}$ \\
\hline AcqAdv & $\begin{array}{l}-0.134 \\
(-0.45)\end{array}$ & $\begin{array}{l}-0.042 \\
(-0.14)\end{array}$ & $\begin{array}{l}-0.070 \\
(-0.24)\end{array}$ & $\begin{array}{l}-0.196 \\
(-0.65)\end{array}$ \\
\hline AcqAge & $\begin{array}{l}0.001 \\
(1.28)\end{array}$ & $\begin{array}{l}0.001 \\
1.03\end{array}$ & $\begin{array}{l}0.001 \\
(1.15)\end{array}$ & $\begin{array}{l}0.001 \\
(0.61)\end{array}$ \\
\hline Cash & $\begin{array}{c}-0.025 * * * \\
(-3.60)\end{array}$ & $\begin{array}{c}-0.024 * * * \\
(-3.38)\end{array}$ & $\begin{array}{c}-0.025 * * * \\
(-3.53)\end{array}$ & $\begin{array}{c}-0.026 * * * \\
(-3.71)\end{array}$ \\
\hline Hostile & $\begin{array}{l}-0.015^{*} \\
(-1.73)\end{array}$ & $\begin{array}{c}-0.015^{*} \\
(-1.76)\end{array}$ & $\begin{array}{c}-0.015^{*} \\
(-1.75)\end{array}$ & $\begin{array}{c}-0.013^{*} \\
(-1.74)\end{array}$ \\
\hline Cross border & $\begin{array}{l}-0.006 \\
(-0.94)\end{array}$ & $\begin{array}{l}-0.005 \\
(-0.78)\end{array}$ & $\begin{array}{l}-0.005 \\
(-0.83)\end{array}$ & $\begin{array}{l}-0.007 \\
(-1.15)\end{array}$ \\
\hline Diversifying & $\begin{array}{l}0.004 \\
(0.47)\end{array}$ & $\begin{array}{l}0.004 \\
(0.51)\end{array}$ & $\begin{array}{l}0.004 \\
(0.47)\end{array}$ & $\begin{array}{l}0.003 \\
(0.33)\end{array}$ \\
\hline Toehold & $\begin{array}{l}-0.012 \\
(-1.15)\end{array}$ & $\begin{array}{l}-0.011 \\
(-1.06)\end{array}$ & $\begin{array}{l}-0.012 \\
(-1.15)\end{array}$ & $\begin{array}{l}-0.011 \\
(-1.06)\end{array}$ \\
\hline Multiple bids & $\begin{array}{c}-0.022^{* *} \\
(-2.25)\end{array}$ & $\begin{array}{c}-0.023^{* *} \\
(-2.36)\end{array}$ & $\begin{array}{c}-0.022^{* *} \\
(-2.33)\end{array}$ & $\begin{array}{c}-0.020^{* *} \\
(-2.13)\end{array}$ \\
\hline Year fixed-effects & Yes & Yes & Yes & Yes \\
\hline Industry fixed-effects & Yes & Yes & Yes & Yes \\
\hline Country fixed-effects & Yes & Yes & Yes & Yes \\
\hline Observations & 726 & 726 & 726 & 726 \\
\hline $\operatorname{Adj}-R^{2}$ & 0.175 & 0.170 & 0.171 & 0.171 \\
\hline
\end{tabular}

The dependent variable represents the arbitrage spread one day after announcement. See Equations (1) and (2) for the calculation of the arbitrage spread. AcqCSR is the acquirer's overall CSR score in column 1, the environmental score in column 2, the social score in column 3 and the governance score in column 4. Bid premium is the percentage difference between the offer price and the target's average price between $\mathrm{t}-30$ to $\mathrm{t}-10$ relative to announcement date. CumRet is the cumulative target's stock price return from $t-42$ to $t-1$ relative to announcement date. AbnVol is abnormal trading volume around acquisition announcements (from t-1 to $t+1$ ). AcqSize is the acquirer's market value. TarSize is the target's market value. TarMTB is the targets' market-to-book ratio. Acq $\mathrm{Q}_{i}$ is the acquirers' Tobin's Q. AcqAR is the acquirers' market-adjusted return. AcqROA is the acquirer's return on asset. AcqCAPEX represents the acquirer's capital expenditures scaled by total assets. AcqCF is the acquirer's cash flow scaled by total assets. AcqLev is the acquirer's debt-to-asset ratio. AcqRD is the acquirer's research and development expenses scaled by total assets. AcqAdv is the acquirer's advertising expenses scaled by total assets. AcqAge is the acquiring firm's age. Cash is a dummy variable that takes a value of one for purely cash-financed deals, and zero otherwise. Hostile is a dummy variable that takes a value of one for hostile bids, and zero otherwise. Cross border is a dummy variable that takes a value of one when the acquirer and the target are not in the same country, and zero otherwise. Diversifying is a dummy variable that takes the value of one if the acquirer and the target have different first two-digit standard industrial classification codes and zero otherwise. Toehold is a dummy variable that takes a value of one if the acquirer holds at least $5 \%$ of the target shares prior to the announcement and zero otherwise. Multiple bids is a dummy variable that takes a value of one if there is more than one acquirer and zero otherwise. Regressions include country, industry and year fixed effects. All financial variables are winsorized at the $1 \%$ and $99 \%$ level. T-statistics are in parentheses. ${ }^{* * *},{ }^{* *}$ and $*$ denote significance at the $1 \%, 5 \%$ and $10 \%$ level respectively. 
Table 6: Acquirer's CSR and likelihood of deal success

\begin{tabular}{|c|c|c|c|c|}
\hline & \multicolumn{4}{|c|}{ Probit regression } \\
\hline & (1) & (2) & (3) & (4) \\
\hline & CSR & Environment & Social & Governance \\
\hline Constant & $-1.917 * *$ & $-1.891 * *$ & $-1.886 * *$ & $-1.908 * *$ \\
\hline \multirow[t]{2}{*}{ AcqCSR } & $0.354 * *$ & $0.347 * *$ & $0.325 * *$ & -0.018 \\
\hline & {$[9.34]$} & [9.10] & {$[8.88]$} & {$[-0.49]$} \\
\hline \multirow[t]{2}{*}{ Bid premium } & 0.166 & 0.177 & 0.159 & 0.167 \\
\hline & [4.36] & [4.65] & [4.18] & [4.40] \\
\hline \multirow[t]{2}{*}{ CumRet } & -0.300 & -0.296 & -0.294 & -0.298 \\
\hline & {$[-7.62]$} & {$[-7.52]$} & {$[-7.47]$} & {$[-7.56]$} \\
\hline \multirow[t]{2}{*}{ AbnVol (x100) } & $0.005^{* *}$ & $0.005^{* *}$ & $0.005^{* *}$ & $0.005^{* * *}$ \\
\hline & [0.13] & {$[0.13]$} & {$[0.13]$} & [0.14] \\
\hline \multirow[t]{2}{*}{ AcqSize } & $0.253^{* * *}$ & $0.244 * * *$ & $0.245^{* * *}$ & $0.257^{* * *}$ \\
\hline & [6.42] & {$[6.21]$} & [6.22] & [6.53] \\
\hline \multirow[t]{2}{*}{ TarSize } & $-0.172 * * *$ & $-0.172 * * *$ & $-0.172 * * *$ & $-0.171^{* * *}$ \\
\hline & {$[-4.36]$} & {$[-4.37]$} & [-4.37] & {$[-4.36]$} \\
\hline \multirow[t]{2}{*}{ TarMTB } & 0.010 & 0.010 & 0.010 & 0.010 \\
\hline & {$[0.26]$} & {$[0.26]$} & {$[0.26]$} & {$[0.26]$} \\
\hline \multirow[t]{2}{*}{$\mathrm{AcqQ}$} & -0.138 & -0.132 & -0.134 & -0.131 \\
\hline & {$[-3.50]$} & {$[-3.37]$} & {$[-3.40]$} & {$[-3.33]$} \\
\hline \multirow[t]{2}{*}{ AcqAR } & $-0.388^{*}$ & $-0.387 *$ & $-0.388^{*}$ & $-0.393 *$ \\
\hline & {$[-9.87]$} & {$[-9.84]$} & {$[-9.87]$} & {$[-9.98]$} \\
\hline \multirow[t]{2}{*}{ AcqROA } & -1.532 & -1.481 & -1.477 & -1.667 \\
\hline & {$[-38.96]$} & {$[-37.67]$} & {$[-37.58]$} & {$[-42.35]$} \\
\hline \multirow[t]{2}{*}{ AcqCAPEX } & 2.183 & 2.161 & 2.167 & 2.151 \\
\hline & [55.52] & [54.97] & [55.12] & [54.64] \\
\hline \multirow[t]{2}{*}{$\mathrm{AcqCF}$} & 1.981 & 1.898 & 1.899 & 2.147 \\
\hline & [50.37] & [48.29] & [48.29] & [54.54] \\
\hline \multirow{2}{*}{ AcqLev } & 0.005 & -0.001 & -0.001 & -0.007 \\
\hline & [0.14] & {$[-0.02]$} & {$[-0.01]$} & {$[-0.17]$} \\
\hline \multirow[t]{2}{*}{ AcqRD } & 2.387 & 2.353 & 2.361 & 2.230 \\
\hline & [60.71] & [59.87] & [60.05] & [56.63] \\
\hline \multirow[t]{2}{*}{ AcqAdv } & 4.979 & 4.964 & 4.991 & 4.214 \\
\hline & [126.62] & [126.27] & [126.96] & [107.04] \\
\hline \multirow[t]{2}{*}{ AcqAge } & 0.001 & 0.001 & 0.001 & 0.001 \\
\hline & {$[0.02]$} & {$[0.02]$} & [0.02] & {$[0.02]$} \\
\hline \multirow[t]{2}{*}{ Cash } & $0.265^{* *}$ & $0.252^{* *}$ & $0.262^{* *}$ & $0.280^{* *}$ \\
\hline & [6.97] & {$[6.63]$} & {$[6.88]$} & {$[7.38]$} \\
\hline \multirow[t]{2}{*}{ Hostile } & $-1.445^{* * *}$ & $-1.446 * * *$ & $-1.446 * * *$ & $-1.439 * * *$ \\
\hline & {$[-36.74]$} & {$[-36.80]$} & {$[-36.79]$} & {$[-36.56]$} \\
\hline \multirow[t]{2}{*}{ Cross border } & 0.001 & -0.002 & -0.002 & -0.007 \\
\hline & {$[0.00]$} & {$[-0.05]$} & {$[-0.04]$} & {$[-0.18]$} \\
\hline Diversifying & -0.034 & -0.038 & -0.038 & -0.032 \\
\hline & {$[-0.86]$} & {$[-0.96]$} & {$[-0.96]$} & {$[-0.81]$} \\
\hline Toehold & $0.297^{*}$ & $0.300^{*}$ & $0.301^{*}$ & $0.295^{*}$ \\
\hline & [7.57] & [7.64] & [7.67] & [7.49] \\
\hline Multiple bids & $-1.060 * * *$ & $-1.061^{* * *}$ & $-1.062 * * *$ & $-1.048 * * *$ \\
\hline & [-26.97] & [-26.99] & {$[-27.01]$} & {$[-26.63]$} \\
\hline Year fixed-effects & Yes & Yes & Yes & Yes \\
\hline Industry fixed-effects & Yes & Yes & Yes & Yes \\
\hline Country fixed-effects & Yes & Yes & Yes & Yes \\
\hline Observations & 726 & 726 & 726 & 726 \\
\hline Pseudo- $R^{2}$ & 0.223 & 0.223 & 0.223 & 0.223 \\
\hline
\end{tabular}

Table 7 reports the results of Probit regression. The dependent variable is a dummy variable that equals one if the deal is completed and zero otherwise. AcqCSR is the acquirer's overall CSR score in column 1, the environmental score in column 2, the social score in column 3 and the governance score in column 4 . Bid premium is the percentage difference between the offer price and the target's average price between t-30 to t-10 relative to announcement date. CumRet is the cumulative target's stock price return from $t-42$ to $t-1$ relative to announcement date. AbnVol is abnormal trading volume around acquisition announcements (from t-1 to t+1). AcqSize is the acquirer's market value. TarSize is the target's market value. TarMTB is the targets' market-to-book ratio. AcqQ is the acquirers' Tobin's Q. AcqAR is the acquirers' market-adjusted return. AcqROA is the acquirer's return on asset. AcqCAPEX represents the acquirer's capital expenditures scaled by total assets. AcqCF is the acquirer's cash flow scaled by total assets. AcqLev is the acquirer's debt-to-asset ratio. AcqRD is the acquirer's research and development expenses scaled by total assets. AcqAdv is the acquirer's advertising expenses scaled by total assets. AcqAge is the acquiring firm's age. Cash is a dummy variable that takes a value of one for purely cash-financed deals, and zero otherwise. Hostile is a dummy variable that takes a value of one for hostile bids, and zero otherwise. Cross border is a dummy variable that takes a value of one when the acquirer and the target are not in the same country, and zero otherwise. Diversifying is a dummy variable that takes the value of one if the acquirer and the target have different first two-digit standard industrial classification codes and zero otherwise. Toehold is a dummy variable that takes a value of one if the acquirer holds at least $5 \%$ of the target shares prior to the announcement and zero otherwise. Multiple bids is a dummy variable that takes a value of one if there is more than one acquirer and zero otherwise. Regressions include country, industry and year fixed effects. All financial variables are winsorized at the $1 \%$ and $99 \%$ level. The numbers in brackets are marginal effects expressed in percentage points. ${ }^{* * *}, * *$ and $*$ denote significance at the $1 \%, 5 \%$ and $10 \%$ level respectively. 
Table 7: Sensitivity Analysis

\begin{tabular}{|c|c|c|c|c|c|}
\hline & \multicolumn{5}{|c|}{ Dependent variable: ArbSpread } \\
\hline & (1) & (2) & (3) & (4) & (4) \\
\hline & Arbitrage spread $(t+2)$ & Ex-crisis & Ex-Financial & Ex-Negative spreads & Ex-US \\
\hline \multirow[t]{2}{*}{ Constant } & $0.085^{* *}$ & $0.083^{* *}$ & $0.085^{*}$ & $0.135^{* * *}$ & 0.089 \\
\hline & $(2.10)$ & $(2.06)$ & $(1.77)$ & $(3.50)$ & $(1.41)$ \\
\hline \multirow[t]{2}{*}{ AcqCSR } & $-0.038 * *$ & $-0.051 * * *$ & $-0.054 * * *$ & $-0.043^{* * *}$ & $-0.067^{* * *}$ \\
\hline & $(-2.32)$ & $(-3.09)$ & $(-2.95)$ & $(-2.74)$ & $(-3.37)$ \\
\hline \multirow[t]{2}{*}{ Bid premium } & $0.075^{* * *}$ & $0.084 * * *$ & $0.073^{* * *}$ & $0.049 * * *$ & $0.099 * * *$ \\
\hline & $(6.05)$ & $(6.59)$ & $(5.23)$ & (3.89) & (6.38) \\
\hline \multirow[t]{2}{*}{ CumRet } & $-0.062 * * *$ & $-0.048 * * *$ & $-0.060 * * *$ & $-0.058 * * *$ & $-0.038 * *$ \\
\hline & $(-4.12)$ & $(-2.92)$ & $(-3.63)$ & $(-3.89)$ & $(-2.08)$ \\
\hline \multirow[t]{2}{*}{ AbnVol (x100) } & -0.001 & -0.001 & -0.001 & -0.001 & -0.001 \\
\hline & $(-1.33)$ & $(-0.80)$ & $(-0.79)$ & $(-1.36)$ & $(-1.10)$ \\
\hline \multirow[t]{2}{*}{ AcqSize } & $-0.006 * *$ & $-0.006 * *$ & $-0.006^{*}$ & $-0.006 * *$ & $-0.007 *$ \\
\hline & $(-2.10)$ & $(-1.97)$ & $(-1.84)$ & $(-2.09)$ & $(-1.92)$ \\
\hline \multirow[t]{2}{*}{ TarSize } & $0.008^{* * *}$ & $0.008 * * *$ & $0.008 * * *$ & $0.007 * * *$ & $0.010 * * *$ \\
\hline & (3.08) & (3.77) & (3.30) & $(3.46)$ & (3.59) \\
\hline \multirow[t]{2}{*}{ TarMTB } & $0.001^{*}$ & $0.001 * *$ & $0.002 * * *$ & 0.001 & $0.001^{* *}$ \\
\hline & (1.71) & $(2.41)$ & $(2.76)$ & $(0.76)$ & $(2.06)$ \\
\hline \multirow[t]{2}{*}{$A c q Q$} & 0.002 & 0.004 & 0.001 & 0.002 & 0.005 \\
\hline & $(0.40)$ & $(0.88)$ & $(0.30)$ & $(0.40)$ & $(0.81)$ \\
\hline \multirow[t]{2}{*}{ AcqAR } & 0.012 & 0.008 & 0.008 & 0.001 & -0.012 \\
\hline & (1.01) & $(0.66)$ & $(0.66)$ & (0.09) & $(-0.82)$ \\
\hline \multirow[t]{2}{*}{ AcqROA } & -0.018 & -0.021 & -0.016 & -0.050 & -0.044 \\
\hline & $(-0.29)$ & $(-0.34)$ & $(-0.24)$ & $(-0.82)$ & $(-0.60)$ \\
\hline \multirow[t]{2}{*}{ AcqCAPEX } & 0.085 & 0.105 & 0.125 & 0.082 & 0.088 \\
\hline & (1.03) & (1.28) & $(1.46)$ & (1.00) & (0.99) \\
\hline \multirow[t]{2}{*}{ AcqCF } & 0.104 & 0.080 & 0.102 & 0.120 & 0.122 \\
\hline & (1.35) & (1.03) & (1.22) & (1.57) & (1.31) \\
\hline \multirow[t]{2}{*}{ AcqLev } & 0.012 & 0.005 & 0.001 & 0.005 & 0.023 \\
\hline & (0.59) & $(0.23)$ & $(0.02)$ & $(0.24)$ & $(0.86)$ \\
\hline \multirow[t]{2}{*}{ AcqRD } & -0.114 & -0.016 & -0.082 & 0.100 & -0.129 \\
\hline & $(-1.11)$ & $(-0.14)$ & $(-0.78)$ & (0.93) & $(-0.89)$ \\
\hline \multirow[t]{2}{*}{ AcqAdv } & -0.006 & -0.323 & -0.138 & -0.340 & -0.179 \\
\hline & $(-0.02)$ & $(-1.04)$ & $(-0.47)$ & $(-1.11)$ & $(-0.75)$ \\
\hline \multirow[t]{2}{*}{ AcqAge } & 0.001 & 0.001 & $0.001^{*}$ & 0.001 & -0.001 \\
\hline & (1.26) & (1.63) & (1.92) & (1.32) & $(-0.07)$ \\
\hline \multirow[t]{2}{*}{ Cash } & $-0.026 * * *$ & $-0.025 * * *$ & $-0.023 * * *$ & $-0.036 * * *$ & $-0.023^{* *}$ \\
\hline & $(-3.69)$ & $(-3.48)$ & $(-3.13)$ & $(-5.12)$ & $(-2.45)$ \\
\hline Hostile & $-0.019 *$ & $-0.018^{*}$ & $-0.022 *$ & 0.017 & -0.002 \\
\hline & $(-1.89)$ & $(-1.72)$ & $(-1.68)$ & (1.21) & $(-0.15)$ \\
\hline Cross border & -0.007 & -0.003 & -0.010 & 0.003 & -0.013 \\
\hline & $(-1.06)$ & $(-0.53)$ & $(-1.42)$ & $(0.40)$ & $(-1.58)$ \\
\hline Diversifying & 0.005 & 0.004 & 0.010 & 0.001 & 0.010 \\
\hline & $(0.63)$ & $(0.49)$ & (1.08) & $(0.05)$ & $(0.87)$ \\
\hline Toehold & -0.003 & -0.009 & -0.015 & -0.016 & -0.005 \\
\hline & $(-0.28)$ & $(-0.82)$ & $(-1.23)$ & $(-1.37)$ & $(-0.48)$ \\
\hline Multiple bids & $-0.022 * *$ & $-0.029 * * *$ & $-0.023 * *$ & 0.003 & $-0.026 * *$ \\
\hline & $(-2.24)$ & $(-2.84)$ & $(-2.18)$ & $(0.24)$ & $(-2.21)$ \\
\hline Year fixed-effects & Yes & Yes & Yes & Yes & Yes \\
\hline Industry fixed-effects & Yes & Yes & Yes & Yes & Yes \\
\hline Country fixed-effects & Yes & Yes & Yes & Yes & Yes \\
\hline Observations & 726 & 670 & 604 & 545 & 489 \\
\hline $\operatorname{Adj}-R^{2}$ & 0.164 & 0.187 & 0.183 & 0.238 & 0.194 \\
\hline
\end{tabular}


Table 8: Acquirer's CSR and arbitrage spreads (accounting for target's CSR)

\begin{tabular}{|c|c|c|c|c|}
\hline & \multicolumn{4}{|c|}{ Dependent variable: ArbSpread } \\
\hline & (1) & $(2)$ & (3) & (4) \\
\hline & CSR & Environment & Social & Governance \\
\hline Constant & $0.111^{*}$ & $0.117^{*}$ & 0.104 & $0.134^{* *}$ \\
\hline & $(1.70)$ & $(1.80)$ & (1.54) & $(2.05)$ \\
\hline AcqCSR & $-0.056 * *$ & $-0.023 * *$ & $-0.042^{* *}$ & $-0.037^{*}$ \\
\hline & $(-2.29)$ & $(-1.97)$ & $(-2.10)$ & $(-1.93)$ \\
\hline TarCSR & -0.002 & -0.017 & 0.013 & 0.006 \\
\hline & $(-0.08)$ & $(-1.09)$ & $(0.77)$ & $(0.32)$ \\
\hline Bid premium & $0.183^{* * *}$ & $0.182^{* * *}$ & $0.183^{* * *}$ & $0.183^{* * *}$ \\
\hline & $(7.31)$ & $(7.27)$ & $(7.30)$ & $(7.30)$ \\
\hline CumRet & $\begin{array}{c}-0.107 * * * \\
(-4.43)\end{array}$ & $\begin{array}{c}-0.106 * * * \\
(-4.37)\end{array}$ & $\begin{array}{c}-0.108^{* * *} \\
(-4.44)\end{array}$ & $\begin{array}{c}-0.107 * * * \\
(-4.41)\end{array}$ \\
\hline AbnVol (x100) & $\begin{array}{c}-0.001^{*} \\
(-1.92)\end{array}$ & $\begin{array}{c}-0.001^{* *} \\
(-2.01)\end{array}$ & $\begin{array}{c}-0.001 * \\
(-1.77)\end{array}$ & $\begin{array}{c}-0.001 * * \\
(-2.00)\end{array}$ \\
\hline AcqSize & $\begin{array}{c}-0.010^{* *} \\
(-2.11)\end{array}$ & $\begin{array}{c}-0.012^{* * *} \\
(-2.72)\end{array}$ & $\begin{array}{c}-0.010^{* *} \\
(-2.31)\end{array}$ & $\begin{array}{c}-0.012 * * * \\
(-2.79)\end{array}$ \\
\hline TarSize & $\begin{array}{c}0.012^{* *} \\
(2.46)\end{array}$ & $\begin{array}{c}0.014^{* * *} \\
(2.86)\end{array}$ & $\begin{array}{c}0.011^{* *} \\
(2.30)\end{array}$ & $\begin{array}{c}0.011^{* *} \\
(2.42)\end{array}$ \\
\hline TarMTB & $\begin{array}{l}0.001 \\
(1.25)\end{array}$ & $\begin{array}{l}0.001 \\
(1.21)\end{array}$ & $\begin{array}{l}0.001 \\
(1.25)\end{array}$ & $\begin{array}{l}0.001 \\
(1.26)\end{array}$ \\
\hline AcqQ & $\begin{array}{l}0.003 \\
(0.35)\end{array}$ & $\begin{array}{l}0.003 \\
(0.42)\end{array}$ & $\begin{array}{l}0.004 \\
(0.44)\end{array}$ & $\begin{array}{l}0.006 \\
(0.77)\end{array}$ \\
\hline AcqAR & $\begin{array}{l}0.022 \\
(1.21)\end{array}$ & $\begin{array}{l}0.018 \\
(1.00)\end{array}$ & $\begin{array}{l}0.023 \\
(1.25)\end{array}$ & $\begin{array}{l}0.024 \\
(1.29)\end{array}$ \\
\hline AcqROA & $\begin{array}{l}-0.107 \\
(-1.03)\end{array}$ & $\begin{array}{l}-0.095 \\
(-0.92)\end{array}$ & $\begin{array}{r}-0.110 \\
(-1.05)\end{array}$ & $\begin{array}{l}-0.101 \\
(-0.97)\end{array}$ \\
\hline AcqCAPEX & $\begin{array}{r}-0.042 \\
(-0.30)\end{array}$ & $\begin{array}{l}-0.030 \\
(-0.22)\end{array}$ & $\begin{array}{l}-0.030 \\
(-0.22)\end{array}$ & $\begin{array}{l}-0.064 \\
(-0.47)\end{array}$ \\
\hline AcqCF & $\begin{array}{l}0.120 \\
(0.98)\end{array}$ & $\begin{array}{l}0.087 \\
(0.72)\end{array}$ & $\begin{array}{l}0.120 \\
(0.98)\end{array}$ & $\begin{array}{l}0.089 \\
(0.74)\end{array}$ \\
\hline AcqLev & $\begin{array}{l}0.004 \\
(0.15)\end{array}$ & $\begin{array}{l}0.002 \\
(0.08)\end{array}$ & $\begin{array}{l}0.003 \\
(0.11)\end{array}$ & $\begin{array}{l}0.001 \\
(0.02)\end{array}$ \\
\hline AcqRD & $\begin{array}{l}0.013 \\
(0.07)\end{array}$ & $\begin{array}{l}0.017 \\
(0.09)\end{array}$ & $\begin{array}{l}0.036 \\
(0.19)\end{array}$ & $\begin{array}{l}-0.020 \\
(-0.11)\end{array}$ \\
\hline AcqAdv & $\begin{array}{l}-0.145 \\
(-0.24)\end{array}$ & $\begin{array}{r}-0.043 \\
(-0.07)\end{array}$ & $\begin{array}{l}-0.056 \\
(-0.09)\end{array}$ & $\begin{array}{l}-0.273 \\
(-0.44)\end{array}$ \\
\hline AcqAge & $\begin{array}{l}0.001 \\
(0.70)\end{array}$ & $\begin{array}{l}0.001 \\
(0.56)\end{array}$ & $\begin{array}{l}0.001 \\
(0.67)\end{array}$ & $\begin{array}{l}0.001 \\
(0.23)\end{array}$ \\
\hline Cash & $\begin{array}{l}-0.020^{*} \\
(-1.94)\end{array}$ & $\begin{array}{c}-0.018^{*} \\
(-1.76)\end{array}$ & $\begin{array}{c}-0.021^{* *} \\
(-2.01)\end{array}$ & $\begin{array}{c}-0.021^{* *} \\
(-2.07)\end{array}$ \\
\hline Hostile & $\begin{array}{l}-0.009 \\
(-0.56)\end{array}$ & $\begin{array}{l}-0.010 \\
(-0.61)\end{array}$ & $\begin{array}{l}-0.011 \\
(-0.66)\end{array}$ & $\begin{array}{l}-0.009 \\
(-0.56)\end{array}$ \\
\hline Cross border & $\begin{array}{l}-0.014 \\
(-1.51)\end{array}$ & $\begin{array}{l}-0.013 \\
(-1.40)\end{array}$ & $\begin{array}{l}-0.011 \\
(-1.24)\end{array}$ & $\begin{array}{c}-0.017^{*} \\
(-1.82)\end{array}$ \\
\hline Diversifying & $\begin{array}{l}0.007 \\
(0.55)\end{array}$ & $\begin{array}{l}0.007 \\
(0.54)\end{array}$ & $\begin{array}{l}0.006 \\
(0.49)\end{array}$ & $\begin{array}{l}0.006 \\
(0.46)\end{array}$ \\
\hline Toehold & $\begin{array}{l}0.004 \\
(0.23)\end{array}$ & $\begin{array}{l}0.008 \\
(0.52)\end{array}$ & $\begin{array}{l}0.004 \\
(0.23)\end{array}$ & $\begin{array}{l}0.005 \\
(0.33)\end{array}$ \\
\hline Multiple bids & $\begin{array}{l}-0.015 \\
(-1.09)\end{array}$ & $\begin{array}{l}-0.017 \\
(-1.23)\end{array}$ & $\begin{array}{l}-0.015 \\
(-1.12)\end{array}$ & $\begin{array}{l}-0.013 \\
(-0.94)\end{array}$ \\
\hline Year fixed-effects & Yes & Yes & Yes & Yes \\
\hline Industry fixed-effects & Yes & Yes & Yes & Yes \\
\hline Country fixed-effects & Yes & Yes & Yes & Yes \\
\hline Observations & 404 & 404 & 404 & 404 \\
\hline Adj- $R^{2}$ & 0.196 & 0.191 & 0.195 & 0.192 \\
\hline
\end{tabular}

The dependent variable represents the arbitrage spreads one day after announcement. See Equations (1) and (2) for the calculation of the arbitrage spread. AcqCSR is the acquirer's overall CSR score in column 1, the environmental score in column 2, the social score in column 3 and the governance score in column 4. TarCSR is the target's overall CSR score in column 1, the environmental score in column 2, the social score in column 3 and the governance score in column 4 . Bid premium is the percentage difference between the offer price and the target's average price between $\mathrm{t}-30$ to $\mathrm{t}-10$ relative to announcement date. CumRet is the cumulative target's stock price return from $t-42$ to $t-1$ relative to announcement date. AbnVol is abnormal trading volume around acquisition announcements (from $\mathrm{t}-1$ to $\mathrm{t}+1$ ). AcqSize is the acquirer's market value. TarSize is the target's market value. TarMTB is the targets' market-to-book ratio. AcqQ $\mathrm{Q}_{\mathrm{i}}$ is the acquirers' Tobin's $Q$. AcqAR is the acquirers' market-adjusted return. AcqROA is the acquirer's return on asset. AcqCAPEX represents the acquirer's capital expenditures scaled by total assets. AcqCF is the acquirer's cash flow scaled by total assets. AcqLev is the acquirer's debt-to-asset ratio. AcqRD is the acquirer's research and development expenses scaled by total assets. AcqAdv is the acquirer's advertising expenses scaled by total assets. AcqAge is the acquiring firm's age. Cash is a dummy variable that takes a value of one for purely cash-financed deals, and zero otherwise. Hostile is a dummy variable that takes a value of one for hostile bids, and zero otherwise. Cross border is a dummy variable that takes a value of one when the acquirer and the target are not in the same country, and zero otherwise. Diversifying is a dummy variable that takes the value of one if the acquirer and the target have different first two-digit standard industrial classification codes and zero otherwise. Toehold is a dummy variable that takes a value of one if the acquirer holds at least $5 \%$ of the target shares prior to the announcement and zero otherwise. Multiple bids is a dummy variable that takes a value of one if there is more than one acquirer and zero otherwise. Regressions include country, industry and year fixed effects. All financial variables are winsorized at the $1 \%$ and $99 \%$ level. T-statistics are in parentheses. $* * *, * *$ and ${ }^{*}$ denote significance at the $1 \%, 5 \%$ and $10 \%$ level respectively. 
Table 9: Acquirer's CSR and arbitrage spreads (removing serial acquirers)

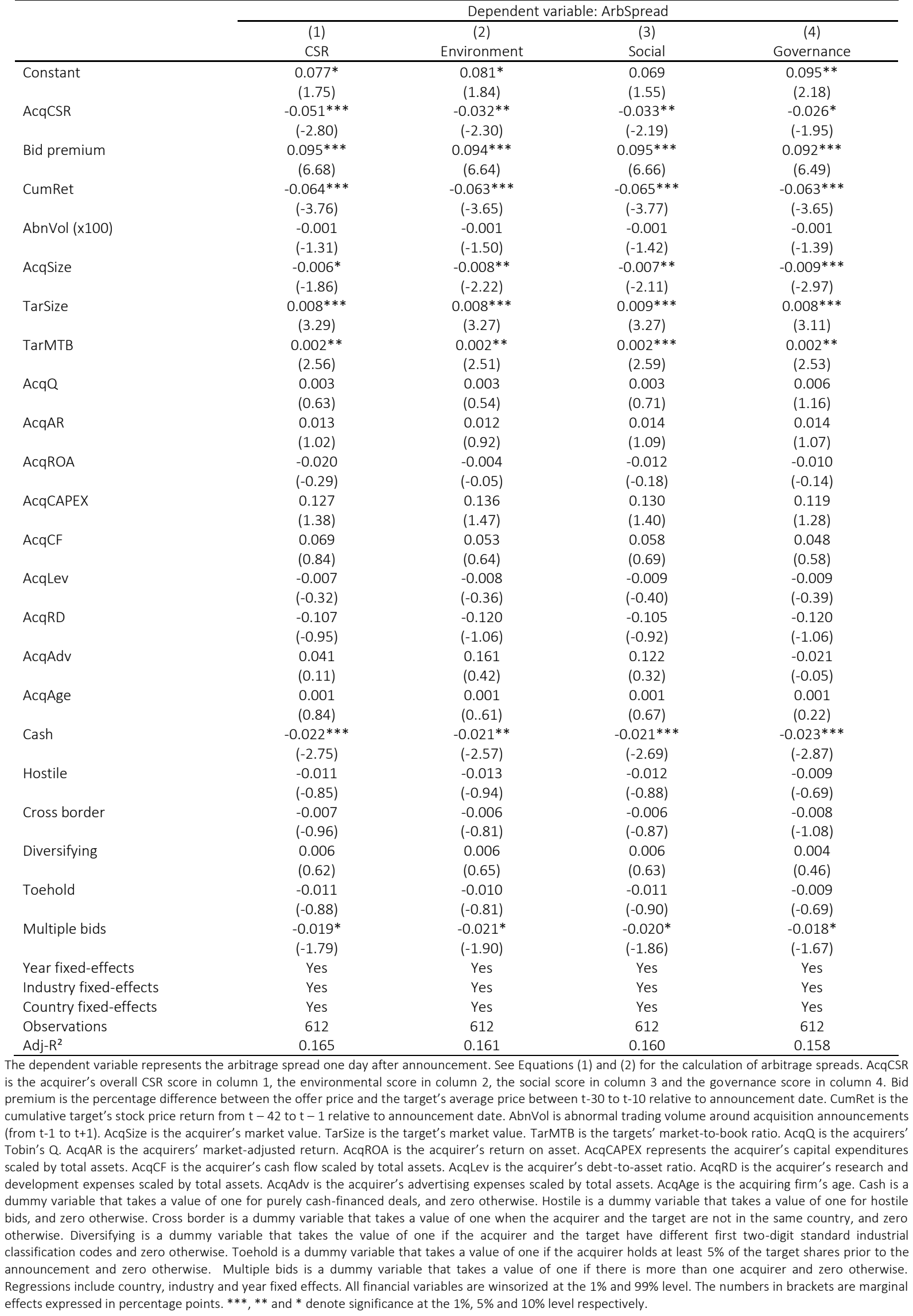


Table 10: Instrumental Variables Estimations

\begin{tabular}{|c|c|c|c|c|c|c|c|c|}
\hline & \multicolumn{2}{|c|}{ CSR } & \multicolumn{2}{|c|}{ Environment } & \multicolumn{2}{|c|}{ Social } & \multicolumn{2}{|c|}{ Governance } \\
\hline & First stage & Second stage & First stage & Second stage & First stage & Second stage & First stage & Second stage \\
\hline & (1) & (2) & (3) & (4) & (5) & (6) & (7) & (8) \\
\hline \multirow[t]{2}{*}{ Constant } & 0.090 & $0.123^{* * *}$ & $0.311^{* *}$ & $0.074^{* *}$ & 0.046 & $0.077^{* *}$ & 0.036 & $0.057^{* *}$ \\
\hline & $(0.97)$ & $(3.85)$ & $(2.51)$ & $(2.02)$ & $(0.42)$ & $(2.02)$ & $(0.45)$ & $(2.20)$ \\
\hline \multirow[t]{2}{*}{ AcqCSR_adj } & & $-0.064 * *$ & & $-0.022 * *$ & & $-0.034 * *$ & & $-0.053 * * *$ \\
\hline & & $(-2.03)$ & & $(-1.99)$ & & $(-2.05)$ & & $(-3.29)$ \\
\hline \multirow[t]{2}{*}{ Country-year CSR } & $0.498 * * *$ & & $0.303 * * *$ & & $0.397^{* * *}$ & & $0.429 * * *$ & \\
\hline & $(4.21)$ & & $(2.45)$ & & (3.54) & & $(4.80)$ & \\
\hline \multirow[t]{2}{*}{ Country-industry CSR } & $0.528 * * *$ & & $0.508 * * *$ & & $0.477^{* * *}$ & & $0.648 * * *$ & \\
\hline & $(6.07)$ & & $(5.61)$ & & (5.43) & & (7.54) & \\
\hline Controls & Yes & Yes & Yes & Yes & Yes & Yes & Yes & Yes \\
\hline $\begin{array}{l}\text { First-stage Cragg and } \\
\text { Donald test }\end{array}$ & $p$-value $<0.001$ & & $p$-value $<0.001$ & & $p$-value $<0.001$ & & $p$-value $<0.001$ & \\
\hline \multicolumn{9}{|l|}{ overidentification test } \\
\hline Observations & 726 & 726 & 726 & 726 & 726 & 726 & 726 & 726 \\
\hline$R^{2}$ & 0.528 & 0.311 & 0.535 & 0.294 & 0.567 & 0.297 & 0.727 & 0.306 \\
\hline
\end{tabular}

